Marquette University

e-Publications@Marquette

Biomedical Engineering Faculty Research and

Publications

Biomedical Engineering, Department of

$10-2017$

\title{
Protection by Inhaled Hydrogen Therapy in a Rat Model of Acute Lung Injury can be Tracked in vivo Using Molecular Imaging
}

Said H. Audi

Marquette University, said.audi@marquette.edu

Elizabeth R. Jacobs

Medical College of Wisconsin

Xiao Zhang

Marquette University

Amadou K.S. Camara

Medical College of Wisconsin

Ming Zhao

Northwestern University

See next page for additional authors

Follow this and additional works at: https://epublications.marquette.edu/bioengin_fac

Part of the Biomedical Engineering and Bioengineering Commons

\section{Recommended Citation}

Audi, Said H.; Jacobs, Elizabeth R.; Zhang, Xiao; Camara, Amadou K.S.; Zhao, Ming; Medhora, Meetha M.; Rizzo, Benjamin Michael; and Clough, Anne V., "Protection by Inhaled Hydrogen Therapy in a Rat Model of Acute Lung Injury can be Tracked in vivo Using Molecular Imaging" (2017). Biomedical Engineering Faculty Research and Publications. 515.

https://epublications.marquette.edu/bioengin_fac/515 


\section{Authors}

Said H. Audi, Elizabeth R. Jacobs, Xiao Zhang, Amadou K.S. Camara, Ming Zhao, Meetha M. Medhora, Benjamin Michael Rizzo, and Anne V. Clough 
Marquette University

e-Publications@Marquette

\section{Biomedical Engineering Faculty Research and Publications/College of} Engineering

This paper is NOT THE PUBLISHED VERSION; but the author's final, peer-reviewed manuscript. The published version may be accessed by following the link in th citation below.

Shock, Vol. 48, No. 4 (October 2017): 467-476. DOI. This article is C Wolters Kluwer and permission has been granted for this version to appear in e-Publications@Marquette. Wolters Kluwer does not grant permission for this article to be further copied/distributed or hosted elsewhere without the express permission from Wolters Kluwer.

\section{Protection by Inhaled Hydrogen Therapy in a Rat Model of Acute Lung Injury can be Tracked in vivo Using Molecular Imaging}

\section{Said Audi}

Department of Biomedical Engineering, Marquette University, Milwaukee, Wisconsin

Zablocki V.A. Medical Center, Milwaukee, Wisconsin

Elizabeth Jacobs

Zablocki V.A. Medical Center, Milwaukee, Wisconsin

Division of Pulmonary and Critical Care Medicine, Medical College of Wisconsin, Milwaukee, Wisconsin

Xiao Zhang

Department of Biomedical Engineering, Marquette University, Milwaukee, Wisconsin

Amadou Camara

Department of Anesthesiology, Medical College of Wisconsin, Milwaukee, Wisconsin

Ming Zhao

Division of Cardiology, Northwestern University, Evanston, Illinois

Meetha Medhora 
Department of Radiation Oncology, Medical College of Wisconsin, Milwaukee, Wisconsin Benjamin Rizzo

Department of Mathematics, Statistics, and Computer Science, Marquette University, Milwaukee, Wisconsin

\section{Anne Clough;}

Zablocki V.A. Medical Center, Milwaukee, Wisconsin

Department of Mathematics, Statistics, and Computer Science, Marquette University, Milwaukee, Wisconsin

ABSTRACT Inhaled hydrogen gas $\left(\mathrm{H}_{2}\right)$ provides protection in rat models of human acute lung injury (ALI). We previously reported that biomarker imaging can detect oxidative stress and endothelial cell death in vivo in a rat model of ALI. Our objective was to evaluate the ability of ${ }^{99 \mathrm{~m}} \mathrm{Tc}$-hexamethylpropyleneamineoxime (HMPAO) and ${ }^{99 \mathrm{~m}} \mathrm{Tc}$-duramycin to track the effectiveness of $\mathrm{H}_{2}$ therapy in vivo in the hyperoxia rat model of ALI. Rats were exposed to room air (normoxia), $98 \% \mathrm{O}_{2}+2 \% \mathrm{~N}_{2}$ (hyperoxia) or $98 \% \mathrm{O}_{2}+2 \% \mathrm{H}_{2}$ (hyperoxia+ $\mathrm{H}_{2}$ ) for up to $60 \mathrm{~h}$. In vivo scintigraphy images were acquired following injection of ${ }^{99 \mathrm{~m}} \mathrm{Tc}-\mathrm{HMPAO}$ or ${ }^{99 \mathrm{~m}} \mathrm{Tc}$-duramycin.

For hyperoxia rats, ${ }^{99 \mathrm{~m}} \mathrm{Tc}$-HMPAO and ${ }^{99 \mathrm{~m}} \mathrm{Tc}$-duramycin lung uptake increased in a time-dependent manner, reaching a maximum increase of $270 \%$ and $150 \%$ at $60 \mathrm{~h}$, respectively. These increases were reduced to $120 \%$ and $70 \%$, respectively, in hyperoxia $+\mathrm{H}_{2}$ rats. Hyperoxia exposure increased glutathione content in lung homogenate $(36 \%)$ more than hyperoxia $+\mathrm{H}_{2}(21 \%)$, consistent with increases measured in ${ }^{99 \mathrm{~m} T c-H M P A O}$ lung uptake. In 60-h hyperoxia rats, pleural effusion, which was undetectable in normoxia rats, averaged 9.3 gram/rat, and lung tissue 3-nitrotyrosine expression increased by $790 \%$. Increases were reduced by $69 \%$ and $59 \%$, respectively, in 60-h hyperoxia $+\mathrm{H}_{2}$ rats. This study detects and tracks the anti-oxidant and anti-apoptotic properties of $\mathrm{H}_{2}$ therapy in vivo after as early as $24 \mathrm{~h}$ of hyperoxia exposure. The results suggest the potential utility of these SPECT biomarkers for in vivoassessment of key cellular pathways in the pathogenesis of ALI and for monitoring responses to therapies.

\section{INTRODUCTION}

Acute lung injury (ALI) is one of the most frequent causes of admission to medical intensive care units $\frac{(1,2)}{\text {. Acute }}$ Respiratory Distress Syndrome (ARDS) occurs in $\sim 250,000$ patients/year in the US, carries a mortality rate that may exceed $40 \%$, lacks early detection tools, and has limited therapies $\frac{(1,2)}{2}$. The most common therapy is ventilation with high concentrations of oxygen (hyperoxia) $\stackrel{(3)}{ }$. However, sustained exposure to high fractions of

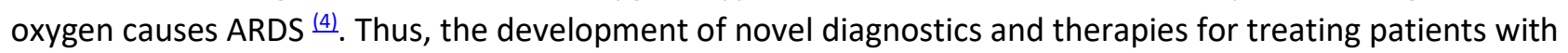
ARDS is urgently needed.

Recent preclinical studies have demonstrated that inhaled hydrogen gas $\left(\mathrm{H}_{2}\right)$ at a concentration of $\sim 2 \%$ provides protection in lung injury animal models of human ALI/ARDS (e.g., ventilation-induced injury, transplant-induced ischemia-reperfusion injury, lipopolysaccharide, and hyperoxic injury) $\stackrel{(5-10)}{2}$, attributed to its potent anti-oxidant, anti-apoptotic, and anti-inflammatory properties. $\mathrm{H}_{2}$ reduces the most damaging oxidants such as hydroxyl radical and peroxynitrite, but has no effect on superoxide, nitric oxide, or hydrogen peroxide and hence does not interfere with their role in cell signaling and/or immune response $\frac{(5,8)}{}$. Additional studies have shown that the anti-apoptotic properties of $\mathrm{H}_{2}$ are associated with inhibition of caspase 3 activation $\stackrel{(8)}{ }$. Moreover, $\mathrm{H}_{2}$ is

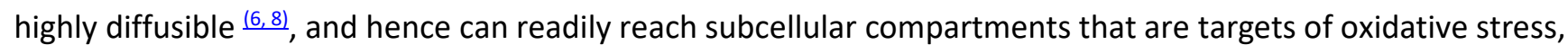
including mitochondria.

Recently, we demonstrated the utility of single-photon emission computed tomography (SPECT) biomarker imaging to detect oxidative stress (using ${ }^{99 \mathrm{~m} T c-h e x a m e t h y l p r o p y l e n e a m i n e ~ o x i m e ~[H M P A O]) ~ a n d ~ e n d o t h e l i a l ~ c e l l ~}$ 
death (using ${ }^{99 \mathrm{~m}} \mathrm{Tc}$-duramycin) in lungs of rats exposed to high concentrations of $\mathrm{O}_{2}$ (hyperoxia) or treated with the endotoxin lipopolysaccharide as models of human ALI/ARDS $\stackrel{(8,11-13)}{2}$. Furthermore, we identified a strong correlation between ${ }^{99 \mathrm{~m}} \mathrm{Tc}-\mathrm{HMPAO}$ uptake and glutathione tissue content $\stackrel{(12)}{ }$, as an indicator of oxidative stress, and between ${ }^{99 \mathrm{~m}} \mathrm{Tc}$-duramycin uptake and cleaved-caspase 3 as a marker of apoptosis ${ }^{(11,14)}$. The objective of this study was to evaluate the potential utility of ${ }^{99 \mathrm{~m}} \mathrm{Tc}-\mathrm{HMPAO}$ and ${ }^{99 \mathrm{~m}} \mathrm{Tc}$-duramycin to track the effectiveness of $\mathrm{H}_{2}$ therapy in vivo in the hyperoxia rat model of human ALI/ARDS.

\section{MATERIALS AND METHODS}

\section{Materials}

HMPAO (Ceretec) was purchased in kit form from GE Healthcare (Arlington Heights, III), and technetium-labeled macroaggregated albumin ( ${ }^{99 \mathrm{~m}} \mathrm{Tc}-\mathrm{MAA}$, particle sizes 20-40 $\mu \mathrm{m}$ ) was purchased from Cardinal Health (Wauwatosa, Wis). Antibodies to 3-nitrotyrosine (3-NT) (Abcam, \# ab52309), and keratin 4-hydroxynonenal (4HNE) (Abcam, \# ab46545) were used with appropriate secondary antibodies (mouse 1:3,000 for 3-NT and rabbit 1:3,000) to measure expression of 3-nitrotyrosine (3-NT) and 4-hydroxynonenal (4-HNE) in lung tissue homogenate. Diethyl maleate (DEM) and other reagent grade chemicals were purchased from Sigma-Aldrich (St. Louis, Mo).

\section{Rat model of human ALI/ARDS}

All treatment protocols were approved by the Institutional Animal Care and Use Committees of the Zablocki Veterans Affairs Medical Center, the Medical College of Wisconsin and Marquette University.

For normoxia (control) rat studies, adult (68-77 days old) male Sprague-Dawley rats (Charles River; $351 \pm 3$ (SE) $\mathrm{g}, \mathrm{n}=42$ ) were exposed to room air in chambers side by side with those exposed to hyperoxia.

For hyperoxia studies, age- and weight-matched rats (341 $\pm 3 \mathrm{~g}, \mathrm{n}=77$ ) were housed in a Plexiglass chamber and exposed to $98 \% \mathrm{O}_{2}+2 \% \mathrm{~N}_{2}$ (pure oxygen mixed with air) for 24,48 , or $60 \mathrm{~h}$ as previously described $\stackrel{(12)}{ }$. To evaluate the therapeutic effect of $2 \% \mathrm{H}_{2}$, age-matched rats $(344 \pm 3 \mathrm{~g}, \mathrm{n}=62$ ) were housed similarly but exposed to $98 \% \mathrm{O}_{2}+2 \% \mathrm{H}_{2}$ (Praxair Inc, Danbury, Conn) for 24 , 48 , or $60 \mathrm{~h}$. For

all hyperoxia and hyperoxia $+\mathrm{H}_{2}$ experiments, the $\mathrm{O}_{2}$ concentration in the chamber was measured using a DD103 DrDAQ Oxygen Sensor (Pico Technology, Cambridgeshire, UK) and was determined to be $>96 \%$. For the hyperoxia $+\mathrm{H}_{2}$ experiments, the $\mathrm{H}_{2}$ concentration in the chamber was measured using a portable hydrogen detector (Model \# 7200P, US Industrial Products Co, Cypress, Calif) and determined to be $>1.8 \%$.

\section{Lung wet-to-dry weight ratio, weight of pleural effusion}

Heart and lungs from a randomly selected subset of each group of rats were isolated as previously described $\frac{(12)}{}$. The lungs were dissected free of the heart, trachea and mainstem bronchi, and total lung wet weight was obtained. The left lung lobe was weighed and dried at $60^{\circ} \mathrm{C}$ for wet-to-dry weight ratio and the remaining lung lobes were used for the histological studies described below $\underline{(12)}$.

For a subset of rats exposed to hyperoxia or hyperoxia $+\mathrm{H}_{2}$, pleural effusion within the chest cavity was determined by inserting cotton gauze into the chest cavity to absorb any pleural effusion ${ }^{(11)}$. The gauze was weighed before and after use and the difference in weights was used to measure pleural effusion.

\section{Histology}

In a randomly selected subset of rats with normoxia $(n=4)$, 48-h hyperoxia $(n=5), 48$-h hyperoxia $+\mathrm{H}_{2}(n=5)$, 60-h hyperoxia $(n=5)$, and 60-h hyperoxia $+\mathrm{H}_{2}(n=4)$ lungs were fixed after inflation in $10 \%$ neutral buffered formalin (Fisher Scientific, Pittsburg, Pa) and embedded in paraffin. Whole-mount sections of lung were cut (4 $\mu \mathrm{m}$ thick), processed and stained with hematoxylin and eosin (H\&E, Richard Allan, Kalamazoo, Mich). Using highresolution jpeg images of the slides, an investigator masked to the treatment groups obtained 3 to 4 
representative images from preselected areas of the lung on each slide, avoiding large vessels, or airways at $\times 100$ (for neutrophils and edema) and $\times 400$ (for alveolar septum thickness). These images were then scored independently and values for each rat averaged for a single "n." We used a 0 to 2 scoring system for neutrophil influx, edema, and thickness of the diffusion barrier (Table 1) recommended by Matute-Bello et al. $\stackrel{(15)}{\text {. }}$

TABLE 1. Endpoints for histological injury grading on a scale of $0-2$ for each of the indices of injury, including neutrophilic influx, edema, and thickness of the alveolar septum

\begin{tabular}{llll}
\hline Histology injury endpoint/score & \multicolumn{1}{c}{0} & & 2 \\
\hline Neutrophilic influx & None to very rare & Perivascular or peribronchiolar only & Intra-alveolar and widely distributed \\
Edema & None to very rare & Proteinacious material in $<5 \%$ and $<20 \%$ field & Proteinacious material in $>20 \%$ field \\
Thickness of alveolar septum & $\leq 1.8 \times$ control thickness & $>1.8$ but $<2.5 \times$ control thickness & $>2.5 \times$ control thickness \\
\hline
\end{tabular}

TABLE 1. Endpoints for histological injury grading on a scale of 0-2 for each of the indices of injury, including neutrophilic influx, edema, and thickness of the alveolar septum

\begin{tabular}{|l|l|l|l|}
\hline $\begin{array}{l}\text { Histology injury } \\
\text { endpoint/score }\end{array}$ & 0 & 1 & 2 \\
\hline Neutrophilic influx & None to very rare & $\begin{array}{l}\text { Perivascular or peribronchiolar } \\
\text { only }\end{array}$ & $\begin{array}{l}\text { Intra-alveolar and widely } \\
\text { distributed }\end{array}$ \\
\hline Edema & None to very rare & $\begin{array}{l}\text { Proteinacious material in }<5 \% \\
\text { and }<20 \% \text { field }\end{array}$ & $\begin{array}{l}\text { Proteinacious material in } \\
>20 \% \text { field }\end{array}$ \\
\hline $\begin{array}{l}\text { Thickness of alveolar } \\
\text { septum }\end{array}$ & $\begin{array}{l}::: 1.8 \times \text { control } \\
\text { thickness }\end{array}$ & $\begin{array}{l}>1.8 \text { but }<2.5 \times \text { control } \\
\text { thickness }\end{array}$ & $>2.5 \times$ control thickness \\
\hline
\end{tabular}

\section{Western blots}

Western blot analysis was carried out as previously described $\stackrel{(16)}{ }$ on whole lung tissue homogenate (protein concentration $30 \mu \mathrm{g} / \mu \mathrm{L}$ ) to quantify the expressions of 3-nitrotyrosine (3-NT) (17) and (4)-hydroxynonenal (4$\mathrm{HNE}) \stackrel{(18)}{\underset{ }{2}}$ as indicators of oxidative stress. The following primary antibodies (Abcam) were used: 3-NT ab52309 and 4-HNE ab46545 with appropriate secondary antibodies.

\section{Bronchoalveolar lavage (BAL)}

Representative rats from normoxia, 48-h hyperoxia, and 48-h hyperoxia $+\mathrm{H}_{2}$ groups were anesthetized with Beuthanasia (40-50 mg/kg i.p.). The trachea was cannulated, the chest opened, and the heart and lungs were removed from the thoracic cavity. The lungs were infused through the trachea with $3 \mathrm{~mL}$ of ice-cold, $\mathrm{Ca}^{2+}$-free phosphate-buffered saline ex vivo ${ }^{(12)}$. The solution was withdrawn and saved for analysis. The procedure was repeated with a second volume of $3 \mathrm{~mL}$ for a total instilled lavage of $6 \mathrm{~mL}$. The returned BAL volume was measured and the cells resuspended by gentle agitation. An aliquot $(1 \mathrm{~mL})$ was removed for determination of total cell counts and protein concentration in the cell-free supernatant. The remainder of the sample was used for cytospin preparations. Cell counts were obtained by resuspending cell pellet from $1 \mathrm{~mL}$ after centrifugation at $1,000 \mathrm{~g}$ for $10 \mathrm{~min}$ in a known volume and counting with a hemocytometer $\stackrel{(12)}{ }$.

\section{Mitochondrial membrane potential}

Representative rats from the normoxia, 48-h hyperoxia, and 48-h hyperoxia $+\mathrm{H}_{2}$ groups were anesthetized, and the lungs rapidly exposed and cleared of residual blood with $50 \mathrm{~mL}$ cold perfusion solution (physiologic saline buffered with $10 \mathrm{mM}$ HEPES ( $\mathrm{pH} 7.4$ ) and containing $5.5 \mathrm{mM}$ glucose) via the right ventricle. The lungs were then removed from the chest, trachea, large airways, and large vessels were removed, after which the peripheral lung was placed in an ice-cold homogenization buffer ( $\mathrm{pH}$ 7.4) containing $10 \mathrm{mM} \mathrm{HEPES,} 200 \mathrm{mM}$ mannitol, $70 \mathrm{mM}$ sucrose, $1 \mathrm{mM}$ EFTA, 2\% fatty acid-free BSA, and protease inhibitor cocktail ( $50 \mu \mathrm{L} / \mathrm{g}$ lung tissue; set III, Calbiochem) and minced over ice. Lung tissue was homogenized using a Tissue Tearer Homogenizer. The 
resulting homogenate was then centrifuged (Sorvall Superspeed RC-5B, Norwalk, Conn) at $2,000 \times \mathrm{g}$ at $4^{\circ} \mathrm{C}$ for 15 $\min$. The supernatant was transferred to a clean tube and centrifuged at $17,800 \times \mathrm{g}$ at $4^{\circ} \mathrm{C}$ for $15 \mathrm{~min}$. The resulting supernatant was discarded and the remaining pellet was resuspended in $5 \mathrm{~mL}$ ice-cold homogenization solution and centrifuged at $17,800 \times \mathrm{g}$ at $4^{\circ} \mathrm{C}$ for $15 \mathrm{~min}$. The supernatant was discarded and the final pellet was resuspended in 0.3 to $4 \mathrm{~mL}$ ice-cold buffer (same as the homogenization buffer without BSA or the protease inhibitor cocktail) and stored on ice to be used for membrane potential studies. Mitochondrial protein was determined using the Pierce BCA protein assay with bovine serum albumin as the standard.

Mitochondrial membrane potential $\left(\Delta \psi_{\mathrm{m}}\right)$ studies were performed at room temperature using a Photon Technology International (PTI) QuantaMaster fluorometer (HORIBA Scientific, Edison, NJ) that monitored and recorded the rhodamine (R123) emission signal (503/527 nm excitation/emission wavelength) continuously over time $\stackrel{(19)}{ }$. Briefly, a cuvette containing $1 \mathrm{~mL}$ of the reaction buffer ( $\mathrm{pH} 7.2), \mathrm{R} 123$ (200 nM), and either pyruvate $(10 \mathrm{mM})+$ malate $(5 \mathrm{mM})$ or succinate $(7 \mathrm{mM})$ was placed on the stage of the fluorometer. After $2 \mathrm{~min}$, mitochondrial protein $(1 \mathrm{mg} / \mathrm{mL})$ was added, and then once the R123 emission signal reached steady-state (state 2), ADP (100 or $50 \mu \mathrm{M})$ was added to evaluate the ADP-stimulated depolarization of $\Delta \psi_{\mathrm{m}}$. The uncoupled $\Delta \psi_{\mathrm{m}}$ was then determined by adding carbonyl cyanide-4-(trifluoromethoxy) henylhydrazone (FCCP, $10 \mu \mathrm{M}$ ). The emission signal was then normalized to its final value reached after the addition of FCCP $\underline{(19)}$.

\section{Glutathione (GSH) content}

Lungs of randomly selected normoxia, 48-h hyperoxia, and hyperoxia $+\mathrm{H}_{2}$ rats were isolated, connected to a ventilation-perfusion system, and washed free of blood using Krebs-Ringer bicarbonate perfusate containing (in mM) $4.7 \mathrm{KCl}, 2.51 \mathrm{CaCl}_{2}, 1.19 \mathrm{MgSO}_{4}, 2.5 \mathrm{KH}_{2} \mathrm{PO}_{4}, 118 \mathrm{NaCl}, 25 \mathrm{NaHCO}_{3}, 5.5$ glucose, and $5 \%$ bovine serum albumin as previously described $\frac{(12,20)}{2}$. Total lung wet weight was obtained and then a portion of the lung was used for the glutathione assay. The 48-h time point was chosen since at this time the increase in HMPAO lung uptake is large enough to evaluate the impact of $\mathrm{H}_{2}$ on GSH content without significant cellular infiltration observed at the 60-h time point.

Lung tissue was dissected free from large airways and connective tissue, and weighed. The tissue was then placed into 10 volumes (per lung wet weight) of $4^{\circ} \mathrm{C}$ sulfosalicylic acid $(5 \%)$, minced, and homogenized. The homogenate was centrifuged $(10,000 \times \mathrm{g})$ at $4^{\circ} \mathrm{C}$ for $20 \mathrm{~min}$, and the supernatant was used to determine lung GSH content as previously described $\frac{(12,20)}{2}$.

\section{Imaging studies}

In vivo imaging studies described below were conducted on randomly selected subsets of rats from each exposure condition group. Sample sizes were chosen to achieve a power $\geq 85 \%$ using power analysis (ANOVA power) based on previously published means and standard deviations of the lung uptake of ${ }^{99 \mathrm{~m}} \mathrm{Tc}-\mathrm{HMPAO}$ and ${ }^{99 m}$ Tc-duramycin $\stackrel{(11-13)}{ }$.

${ }^{99 \mathrm{~m}} \mathrm{Tc}-\mathrm{HMPAO}$ and ${ }^{99 \mathrm{~m}} \mathrm{Tc}$-duramycin were constituted and labeled according to kit directions as previously described $\stackrel{(11,12)}{ }$, while ${ }^{99 \mathrm{~m} T c-m a c r o a g g r e g a t e d ~ a l b u m i n ~(M A A) ~ w a s ~ o b t a i n e d ~ i n ~ i t s ~ l a b e l e d ~ f o r m . ~ R a t s ~ w e r e ~}$ anesthetized with sodium pentobarbital $(40-50 \mathrm{mg} / \mathrm{kg}$, i.p.) and a femoral vein was cannulated. The rat was then placed supine on a plexiglass plate $(4 \mathrm{~mm}$ ) positioned directly on the face of a parallel-hole collimator (hole diameter $=2 \mathrm{~mm}$, depth $=25 \mathrm{~mm}$ ) attached to a modular gamma camera (Radiation Sensors, LLC) for planar imaging ${ }^{(11,12)}$. An injection (37-74 MBq) of ${ }^{99 \mathrm{~m}} \mathrm{Tc}-\mathrm{HMPAO}$ or ${ }^{99 \mathrm{~m}} \mathrm{Tc}$-duramycin was administered via the femoral vein catheter. Both agents reach steady state in the lung by 20 min postinjection, at which time a 1-min planar image of ${ }^{99 \mathrm{~m}} \mathrm{Tc}$-HMPAO or ${ }^{99 \mathrm{~m}} \mathrm{Tc}$-duramycin was acquired $\stackrel{(11,12)}{ }$.

To investigate the role of the anti-oxidant GSH in the lung retention of ${ }^{99 \mathrm{~m}} \mathrm{Tc}-\mathrm{HMPAO}$, a random subset of rats

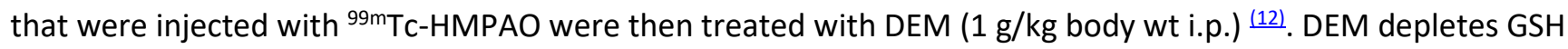


by conjugating with it to form a thioether conjugate via a reaction catalyzed by the enzyme glutathione-Stransferase $\underline{12)}$. Forty-five minutes after DEM treatment and without relocation of the rat, a second injection of ${ }^{99 \mathrm{~m}} \mathrm{Tc}-\mathrm{HMPAO}$ was made and the animal reimaged $20 \mathrm{~min}$ later.

Then in all rats, a final injection of ${ }^{99 \mathrm{~m}} \mathrm{Tc}-\mathrm{MAA}$ ( $37 \mathrm{MBq}$ ) was made via the same femoral cannula and the rat reimaged. The ${ }^{99 \mathrm{~m}} \mathrm{Tc}-\mathrm{MAA}$ injection provided a planar image in which the lung boundaries were clearly identified, since $>95 \%$ of ${ }^{99 m}$ Tc-MAA lodged in the lungs. After imaging, the rats were euthanized with an overdose of pentobarbital. For a subset of the imaged rats, the lungs were removed, fixed inflated with paraformaldehyde, and then following ${ }^{99 m} \mathrm{Tc}$ decay for $72 \mathrm{~h}$ ( $\sim 12$ half-lives), used for histological studies described above.

Image analysis

Images were analyzed using MATLAB-based software developed in-house. The boundaries of the upper portion of the lungs were identified in the high-sensitivity ${ }^{99 \mathrm{~m}} \mathrm{Tc}-\mathrm{MAA}$ images and manually outlined to construct a lung region of interest (ROI) free of liver contribution $\frac{(12)}{2}$. The ${ }^{99 m}$ Tc-MAA lung ROI mask was then superimposed on the ${ }^{99 \mathrm{~m}} \mathrm{Tc}-\mathrm{HMPAO}$ or ${ }^{99 \mathrm{~m}} \mathrm{Tc}$-duramycin images yielding a lung ${ }^{99 \mathrm{~m}} \mathrm{Tc}-\mathrm{HMPAO}$ or ${ }^{99 \mathrm{~m}} \mathrm{Tc}$-duramycin ROI. No registration was required since the animal was maintained in the same location throughout the imaging study. Background regions in the upper forelimbs were also identified in the ${ }^{99 \mathrm{~m}} \mathrm{Tc}-\mathrm{HMPAO}$ or ${ }^{99 \mathrm{~m}} \mathrm{Tc}$-duramycin images

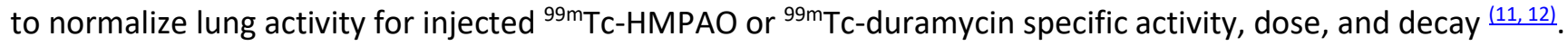
Mean counts/sec/pixel/injected dose within both the lung and forelimb-background ROls were then determined and decay corrected. The ratio of the lung and background ROI signals averaged over the 15 to 20 min time

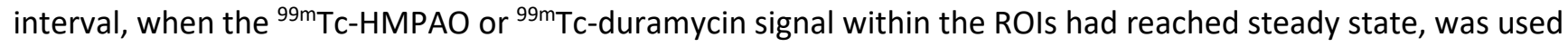

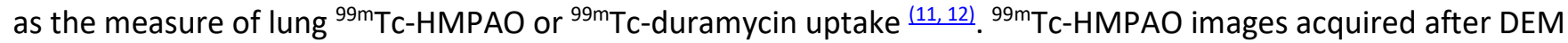
treatment were analyzed in the same way except that the pre-injection baseline activity level within each ROI was subtracted from the corresponding postinjection activity level to account for residual ${ }^{99 \mathrm{~m}} \mathrm{Tc}-\mathrm{HMPAO}$ from the first injection $\frac{(12)}{2}$.

\section{Statistical analysis}

Statistical evaluation of data was carried out using SigmaPlot version 12.0 (Systat Software Inc, San Jose, Calif). The level of statistical significance was set at 0.05 . Results are expressed as means \pm SE unless stated otherwise. To evaluate differences between means of groups at different exposure times with the same treatment (hyperoxia, hyperoxia + DEM, hyperoxia $+\mathrm{H}_{2}$, or hyperoxia $+\mathrm{H}_{2}+\mathrm{DEM}$ ), one-way ANOVA followed by Tukey range test or Kruskal-Wallis one-way ANOVA on Ranks was used. To evaluate differences pre and post DEM for a given group, a paired two-tailed $t$ test was used. To evaluate differences between hyperoxia and hyperoxia $+\mathrm{H}_{2}$ at a given exposure time, an unpaired two-tailed $t$ test was used. For histology, scores of two graders were averaged, then performance of the groups compared by Kruskal-Wallis one-way ANOVA on Ranks.

\section{RESULTS}

Body weights, lung wet weight, lung wet/dry weight ratios, and pleural effusion Treatment with $\mathrm{H}_{2}$ had no effect on the hyperoxia-induced increase or decrease in body weight at 24 or $60 \mathrm{~h}$ (Table 2). However, the loss in body weight after $48 \mathrm{~h}$ of exposure was smaller $(0.98 \pm 0.34 \%)$ with hyperoxia $+\mathrm{H}_{2}$ as compared with hyperoxia alone $(2.12 \pm 0.32 \%)$. 
TABLE 2. Body weight (BW) pre- and post-treatment

\begin{tabular}{|c|c|c|c|}
\hline Groups (n) & $\begin{array}{l}\text { Pre-BW } \\
\text { (g) }\end{array}$ & $\begin{array}{l}\text { Post-BW } \\
\text { (g) }\end{array}$ & $\begin{array}{c}\% \text { change } \\
\text { in } \mathrm{BW}\end{array}$ \\
\hline 24-h: hyperoxia (8) & $346 \pm 3$ & $350 \pm 3$ & $1.04 \pm 0.73$ \\
\hline 24-h: hyperoxia $+\mathrm{H}_{2}(7)$ & $347 \pm 3$ & $\begin{array}{c}351 \pm 3^{*} \\
(P=0.047)\end{array}$ & $1.33 \pm 0.53$ \\
\hline 48-h: hyperoxia (45) & $339 \pm 4$ & $\begin{array}{c}332 \pm 4^{*} \\
(P<0.001)\end{array}$ & $-2.12 \pm 0.32$ \\
\hline 48-h: hyperoxia $+\mathrm{H}_{2}(41)$ & $344 \pm 5$ & $\begin{array}{c}341 \pm 5^{*} \\
(P<0.001)\end{array}$ & $\begin{array}{c}-0.98 \pm 0.34^{\ddagger} \\
(P=0.018)\end{array}$ \\
\hline 60-h: hyperoxia (24) & $344 \pm 4$ & $\begin{array}{c}325 \pm 4^{\dagger} \\
(P<0.001)\end{array}$ & $-5.36 \pm 0.57$ \\
\hline 60-h: hyperoxia $+\mathrm{H}_{2}(14)$ & $340 \pm 4$ & $\begin{array}{c}321 \pm 4^{*} \\
(P<0.001)\end{array}$ & $-5.52 \pm 0.64$ \\
\hline
\end{tabular}

"Different from corresponding prebody weight (paired Student $t$ test). ${ }^{\dagger}$ Different from corresponding prebody weight (Wilcoxon Signed Rank

test).

${ }^{\ddagger}$ Different from $48 \mathrm{~h}$ hyperoxia (unpaired Student $t$ test).

$\mathrm{n}$ indicates number of rats.

TABLE 2. Body weight (BW) pre- and post-treatment

\begin{tabular}{|l|c|c|c|}
\hline Groups (n) & Pre-BW (g) & Post-BW (g) & $\%$ change in BW \\
\hline 24-h: hyperoxia (8) & $346 \pm 3$ & $350 \pm 3$ & $1.04 \pm 0.73$ \\
\hline 24-h: hyperoxia + H2 (7) & $347 \pm 3$ & $\begin{array}{c}351 \pm 3^{*} \\
(\mathrm{P}=0.047)\end{array}$ & $1.33 \pm 0.53$ \\
\hline 48-h: hyperoxia (45) & $339 \pm 4$ & $\begin{array}{c}332 \pm 4^{*} \\
(P<0.001)\end{array}$ & $-2.12 \pm 0.32$ \\
\hline $\begin{array}{l}\text { 48-h: hyperoxia + } \mathrm{H}_{2} \\
\text { (41 }\end{array}$ & $344 \pm 5$ & $\begin{array}{c}341 \pm 5^{*} \\
(\mathrm{P}<0.001)\end{array}$ & $\begin{array}{c}-0.98 \_0.34^{\ddagger} \\
(P=0.018)\end{array}$ \\
\hline 60-h: hyperoxia (24) & $344 \pm 4$ & $\begin{array}{c}325 \pm 4 \dagger \\
(P<0.001)\end{array}$ & $-5.36 \pm 0.57$ \\
\hline 60-h: hyperoxia $+\mathrm{H}_{2}(14)$ & $340 \pm 4$ & $\begin{array}{c}321 \pm 4^{*} \\
(P<0.001)\end{array}$ & $-5.52 \pm 0.64$ \\
\hline
\end{tabular}

*Different from corresponding prebody weight (paired Student $t$ test).

'Different from corresponding prebody weight (Wilcoxon Signed Rank test).

'Different from $48 \mathrm{~h}$ hyperoxia (unpaired Student $t$ test).

$\mathrm{n}$ indicates number of rats.

Rat exposure to hyperoxia for 48 or $60 \mathrm{~h}$ increased left lobe wet weight/body weight ratio by $35 \%$ and $79 \%$, respectively, as compared with that of normoxia rats (Table 3 ). Inclusion of $\mathrm{H}_{2}$ in the chamber gas mixture did not have a significant effect on this increase. The wet-to-dry weight ratio at $24 \mathrm{~h}$ was greater with hyperoxia $+\mathrm{H}_{2}$ than with hyperoxia alone, but not at 48 or $60 \mathrm{~h}$.

\begin{tabular}{lcc} 
& TABLE 3. Lung weights & \\
\hline & $\begin{array}{c}\text { Left lobe wet } \\
\text { weight/body } \\
\text { weight }(\mathrm{mg} / \mathrm{g})(\mathrm{n})\end{array}$ & $\begin{array}{c}\text { Left lobe } \\
\text { wet/dry ratio }(\mathrm{n})\end{array}$ \\
\hline & & \\
\hline Group & $1.23 \pm 0.02(18)$ & $5.36 \pm 0.07(18)$ \\
Normoxia & $1.22 \pm 0.05(5)$ & $4.82 \pm 0.07(5)$ \\
24-h: hyperoxia & $1.30 \pm 0.03(4)$ & $5.31 \pm 0.05^{\dagger}(4)$ \\
24-h: hyperoxia $+\mathrm{H}_{2}$ & $1.55 \pm 0.07^{*}(15)$ & $5.55 \pm 0.08(18)$ \\
48-h: hyperoxia & $(P<0.001)$ & \\
& $1.45 \pm 0.04^{*}(22)$ & $5.55 \pm 0.10(23)$ \\
48-h: hyperoxia $+\mathrm{H}_{2}$ & $(P<0.001)$ & \\
& $2.16 \pm 0.09^{*}(10)$ & $5.87 \pm 0.24(12)$ \\
60-h: hyperoxia & $(P<0.001)$ & \\
& $2.22 \pm 0.14^{*}(12)$ & $6.14 \pm 0.23^{*}(12)$ \\
60-h: hyperoxia $+\mathrm{H}_{2}$ & $(P<0.001)$ & $(P=0.014)$ \\
&
\end{tabular}

Kruskal-Wallis one-way ANOVA on Ranks followed by Dunn test.

*Different from normoxia.

${ }^{\dagger}$ Different from $24 \mathrm{~h}$ hyperoxia (unpaired Student $t$ test).

$\mathrm{n}$ indicates number of rats. 
$T_{A B L E}$ 3. Lung weights

\begin{tabular}{|l|c|c|}
\hline & Left lobe wet weight/body weight $(\mathrm{mg} / \mathrm{g})(\mathrm{n})$ & Left lobe wet/dry ratio $(\mathrm{n})$ \\
\hline Group & $1.23 \pm 0.02(18)$ & \\
\hline Normoxia & $1.22 \pm 0.05(5)$ & $5.36 \pm 0.07(18)$ \\
\hline 24-h: hyperoxia & $1.30 \pm 0.03(4)$ & $4.82 \pm 0.07(5)$ \\
\hline 24-h: hyperoxia $+\mathrm{H}_{2}$ & $\begin{array}{c}5.31 \pm 0.05^{\dagger}(4) \\
(P=0.001)\end{array}$ \\
\hline 48-h: hyperoxia & $\begin{array}{c}1.55 \pm 0.07^{*}(15) \\
(P<0.001)\end{array}$ & $5.55 \pm 0.08(18)$ \\
\hline 48-h: hyperoxia + $\mathrm{H}_{2}$ & $\begin{array}{c}1.45 \pm 0.04^{*}(22) \\
(P<0.001)\end{array}$ & $5.55 \pm 0.10(23)$ \\
\hline 60-h: hyperoxia & $2.16 \pm 0.09^{*}(10)$ & $5.87 \pm 0.24(12)$ \\
\hline 60-h: hyperoxia $+\mathrm{H}_{2}$ & $(P<0.001)$ & $6.14 \pm 0.23^{*}(12)$ \\
& $2.22 \pm 0.14^{*}(12)$ & $(P=0.014)$ \\
\hline
\end{tabular}

Kruskal-Wallis one-way ANOVA on Ranks followed by Dunn test.

*Different from normoxia.

${ }^{+}$Different from $24 \mathrm{~h}$ hyperoxia (unpaired Student $t$ test).

$\mathrm{n}$ indicates number of rats.

No measurable pleural effusion was observed in any of the groups of rats except for 60-h hyperoxia and 60h hyperoxia $+\mathrm{H}_{2}$. Table 4 shows that inclusion of $\mathrm{H}_{2}$ in the chamber gas mixture reduced by pleural effusion within the chest cavity at this time point.

\begin{tabular}{|c|c|c|c|}
\hline Group & 3-NT (n) & 4-HNE (n) & Pleural effusion $(g)(n)$ \\
\hline Normoxia & $1.0 \pm 0.332(6)$ & $1.0 \pm 0.34(6)$ & NG \\
\hline 48-h: hyperoxia & $\begin{aligned} 3.21 & \pm 0.75^{\circ}(6) \\
(P & =0.023)\end{aligned}$ & $1.52 \pm 0.47(6)$ & NG \\
\hline 48-h: hyperoxia $+\mathrm{H}_{2}$ & $\begin{aligned} 3.07 & \pm 0.77^{*}(6) \\
(P & =0.041)\end{aligned}$ & $0.94 \pm 0.28(6)$ & NG \\
\hline Normoxia & $1.0 \pm 0.113(6)$ & $1.0 \pm 0.15(6)$ & NG \\
\hline 60-h: hyperoxia & $\begin{aligned} 8.87 & \pm 1.68^{*}(6) \\
(P & =0.002)\end{aligned}$ & $1.48 \pm 0.30(6)$ & $9.3 \pm 0.6(17)$ \\
\hline 60-h: hyperoxia $+\mathrm{H}_{2}$ & $\begin{array}{c}4.25 \pm 0.78^{*, t}(6) \\
\cdot(P=0.002) \\
{ }^{\dagger}(P=0.032)\end{array}$ & $1.62 \pm 0.42(6)$ & $\begin{array}{c}2.9 \pm 0.6^{\dagger}(15) \\
(P<0.001)\end{array}$ \\
\hline
\end{tabular}

$T_{A B L E}$ 4. Effect of $H_{2}$ on injury endpoints

\begin{tabular}{|l|c|c|c|}
\hline Group & 3-NT (n) & 4-HNE (n) & Pleural effusion (g) (n) \\
\hline Normoxia & $1.0 \pm 0.332(6)$ & $1.0 \pm 0.34(6)$ & NG \\
\hline 48-h: hyperoxia & $\begin{array}{c}3.21 \pm 0.75^{*}(6) \\
(P=0.023)\end{array}$ & $1.52 \pm 0.47(6)$ & NG \\
\hline 48-h: hyperoxia + $\mathrm{H}_{2}$ & $\begin{array}{c}3.07 \pm 0.77^{*}(6) \\
\left(P \frac{1}{4} 0.041\right)\end{array}$ & $0.94 \pm 0.28(6)$ & NG \\
\hline Normoxia & $1.0 \pm 0.113(6)$ & $1.0 \pm 0.15(6)$ & NG \\
\hline 60-h: hyperoxia & $\begin{array}{c}8.87 \pm 1.68^{*}(6) \\
(P=0.002)\end{array}$ & $1.48 \pm 0.30(6)$ & $9.3 \pm 0.6(17)$ \\
\hline 60-h: hyperoxia + $\mathrm{H}_{2}$ & $\begin{array}{c}4.25 \pm 0.78^{*},+(6) \\
(P=0.002) \\
\end{array}$ & $1.62 \pm 0.42(6)$ & $2.9 \pm 0.6^{+}(15)$ \\
& & $(P<0.001)$ \\
\hline
\end{tabular}


3-NT and 4-HNE band density normalized to $b$ actin and resulting values normalized to normoxia. Unpaired Student $t$ test or Mann-Whitney rank sum

test.

*Different from normoxia.

${ }^{+}$Different from 60-h hyperoxia.

$\mathrm{n}$ indicates number of rats; NG, negligible.

\section{Indices of oxidative stress}

Table 4 shows that expression of 3-NT, as an indicator of oxidative stress, was elevated following $60 \mathrm{~h}$ of exposure to hyperoxia alone. This increase was reduced by $50 \%$ in the animals exposed to hyperoxia $+\mathrm{H}_{2}$. The expression of another indicator of oxidative stress (4-HNE) was not elevated following rat exposure to hyperoxia or hyperoxia $+\mathrm{H}_{2}$.

\section{Histology}

Images of representative lung sections stained with H\&E appear in Figure 1. Lung histology from rats exposed to hyperoxia for 24 or $48 \mathrm{~h}$ was indistinguishable from normoxia rats including scores for neutrophilic influx, edema, or thickness of the diffusion barrier (Table 5; $48 \mathrm{~h}$ data not shown). Samples from lungs of rats exposed to hyperoxia for $60 \mathrm{~h}$ exhibited variable degrees of edema, neutrophilic influx and, by high power, an increase in the width of the alveolar septum (diffusion barrier) relative to controls. Samples from rats exposed to hyperoxia $+\mathrm{H}_{2}$ for $60 \mathrm{~h}$ were not different from those of normoxia rats and were different from hyperoxia alone with respect to neutrophilic influx and barrier thickness. These data support protection by $\mathrm{H}_{2}$ relative to injury of rats exposed to 60 -h hyperoxia alone. 


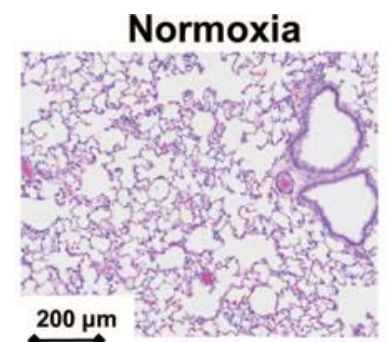

$60 \mathrm{hrs}$

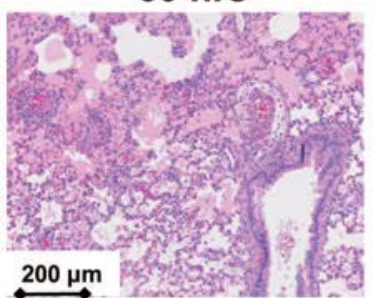

Normoxia

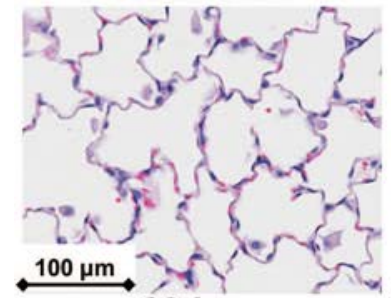

$60 \mathrm{hrs}$
$48 \mathrm{hrs}$

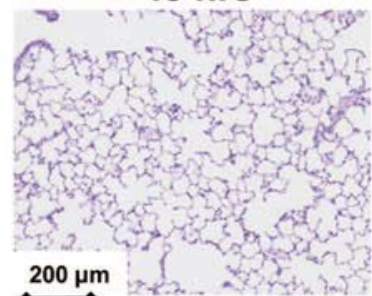

$60 \mathrm{hrs}+\mathrm{H}_{2}$

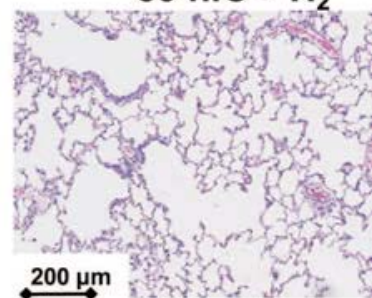

\section{$48 \mathrm{hrs}$}

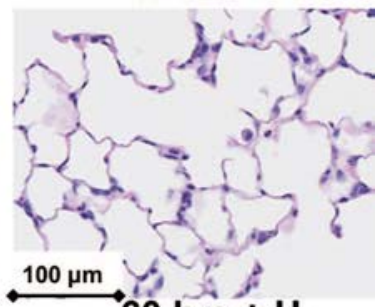

$60 \mathrm{hrs}+\mathrm{H}_{2}$

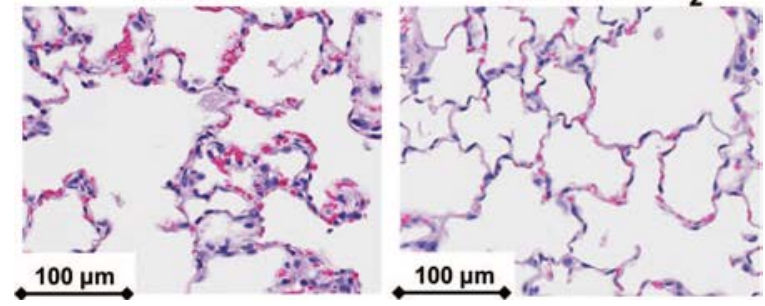

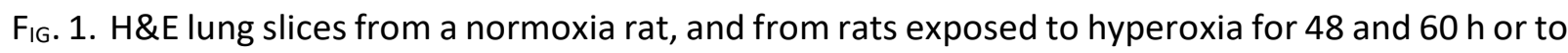
hyperoxia $\mathrm{H}_{2}$ for $60 \mathrm{~h}$. Top panels are at lower power than lower panels to facilitate assessment of neutrophilic influx and edema. Higher power images were used to assess thickness of the alveolar septum. H\&E indicates hematoxylin and eosin.

\begin{tabular}{|c|c|c|c|}
\hline Group (n) & Neutrophils & Edema & $\begin{array}{c}\text { Thickness } \\
\text { diffusion } \\
\text { barrier }\end{array}$ \\
\hline Normoxia (4) & $0 \pm 0$ & $0 \pm 0$ & $0 \pm 0$ \\
\hline 60-h: hyperoxia (5) & $\begin{array}{l}1.40 \pm 0.16^{*} \\
(P<0.001)\end{array}$ & $0.33 \pm 0.19$ & $\begin{array}{l}1.09 \pm 0.09 \\
(P<0.001)\end{array}$ \\
\hline 60-h: hyperoxia $+\mathrm{H}_{2}(4)$ & $\begin{array}{l}0.08 \pm 0.08^{\dagger} \\
(P<0.001)\end{array}$ & $0 \pm 0$ & $\begin{array}{l}0.25 \pm 0.13^{1} \\
(P<0.001)\end{array}$ \\
\hline
\end{tabular}

\section{TABLE 5. H\&E inflammation scores}

\begin{tabular}{|l|c|c|c|}
\hline Group ( $\mathrm{n})$ & Neutrophils & Edema & Thickness diffusion barrier \\
\hline Normoxia (4) & $0 \pm 0$ & $0 \pm 0$ & $0 \pm 0$ \\
\hline 60-h: hyperoxia (5) & $\begin{array}{c}1.40 \pm 0.16^{*} \\
(P<0.001)\end{array}$ & $0.33 \pm 0.19$ & $\begin{array}{c}1.09 \pm 0.09^{*} \\
(P<0.001)\end{array}$ \\
\hline 60-h: hyperoxia $+\mathrm{H}_{2}(4)$ & $0.08 \pm 0.08^{\dagger}$ & $0 \pm 0$ & $0.25 \pm 0.13^{\dagger}$ \\
\hline
\end{tabular}




\begin{tabular}{|l|l|l|l|}
\hline & $(P<0.001)$ & $(P<0.001)$ \\
\hline
\end{tabular}

Kruskal-Wallis one-way ANOVA on ranks followed by Dunn test.

*Different from normoxia.

${ }^{+}$Different from hyperoxia.

$H \& E$ indicates hematoxylin and eosin; $n$, number of rats.

\section{BAL protein and cell counts}

Protein concentration in BAL was greater, compared with normoxic controls, in 48-h hyperoxia (150\%) and 48h hyperoxia $+\mathrm{H}_{2}(63 \%)$ rats (Table 6). Total cell count in BAL was higher in 48-h hyperoxia rats than in hyperoxia $+\mathrm{H}_{2}$ rats (Table 6 ).

\begin{tabular}{lcc}
\multicolumn{2}{c}{ TABLE 6. BAL protein and cell counts } \\
\hline & $\begin{array}{c}\text { Protein } \\
(\mathrm{mg} / \mathrm{mL})\end{array}$ & $\begin{array}{c}\text { Cell count } \\
\left(\times 10^{4}\right) \text { in } \\
\text { collected BAL fluid }\end{array}$ \\
Group (n) & $0.73 \pm 0.03$ & $91 \pm 22$ \\
\hline Normoxia (6) & $1.82 \pm 0.36^{*}$ & $76 \pm 5$ \\
48-h: hyperoxia (5) & $(P=0.009)$ & $48 \pm 5^{*, \dagger}$ \\
& $1.19 \pm 0.15^{*}$ & ${ }^{*}(P=0.041), "(P=0.005)$ \\
48-h: hyperoxia $+\mathrm{H}_{2}(6)$ & $(P=0.041)$ &
\end{tabular}

Unpaired Student $t$ test or Mann-Whitney rank sum test.

Different from normoxia.

${ }^{\dagger}$ Different from hyperoxia.

BAL indicates bronchoalveolar lavage; $n$, number of rats.

$\mathrm{T}_{\mathrm{ABLE}}$ 6. BAL protein and cell counts

\begin{tabular}{|c|c|c|}
\hline Group (n) & Protein $(\mathrm{mg} / \mathrm{mL})$ & Cell count $\left(\times 10^{4}\right)$ in collected BAL fluid \\
\hline Normoxia (6) & $0.73 \pm 0.03$ & $91 \pm 22$ \\
\hline 48-h: hyperoxia (5) & $\begin{array}{c}1.82 \pm 0.36^{*} \\
(P=0.009)\end{array}$ & $76 \pm 5$ \\
\hline 48-h: hyperoxia $+\mathrm{H}_{2}(6)$ & $\begin{array}{c}1.19 \pm 0.15^{*} \\
(P=0.041)\end{array}$ & $\begin{array}{c}48 \pm 5^{*},+ \\
*(P=0.041), \quad \#(P=0.005)\end{array}$ \\
\hline
\end{tabular}

Unpaired Student $t$ test or Mann-Whitney rank sum test.

* Different from normoxia.

'Different from hyperoxia.

BAL indicates bronchoalveolar lavage; $n$, number of rats.

\section{Mitochondrial membrane potential $\left(\Delta \psi_{\mathrm{m}}\right)$}

We quantified ADP-stimulated depolarization of $\Delta \psi_{m}$ in mitochondria isolated from normoxia, hyperoxia, and hyperoxia $+\mathrm{H}_{2}$ rat lungs using R123. Figure 2 shows that in the presence of mitochondria and pyruvate + malate (complex I substrates), the addition of ADP (state 3 ) stimulated a transient and reversible efflux of R123 from mitochondria, consistent with transient and reversible partial depolarization of $\Delta \psi_{\mathrm{m}} \frac{(19)}{}$. Addition of the mitochondrial uncoupler FCCP depolarized $\Delta \psi_{\mathrm{m}}$ resulting in the maximal efflux of R123 from mitochondria $\frac{(19,21)}{2}$. Similar results were obtained with succinate (complex II substrate) as substrate. One measure of the kinetics of ADP-stimulated $\Delta \psi_{m}$ depolarization and repolarization is the full width at half maximum time (FWHM) for R123 return to baseline (state 4), see Figure 2. Table 7 shows that rat exposure to hyperoxia for $48 \mathrm{~h}$ increased FWHM time by $\sim 50 \%$. This suggests that $\Delta \psi_{\mathrm{m}}$ recovery from ADP-induced depolarization in mitochondria from hyperoxia lungs was substantially slower than that in normoxia lungs, consistent with decreases in complex

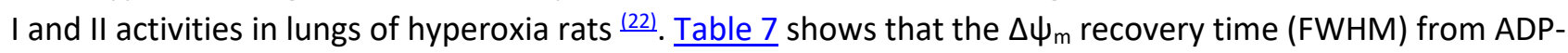
stimulated depolarization, which increased with hyperoxia, partially reversed with hyperoxia $+\mathrm{H}_{2}$, consistent with the ability of $\mathrm{H}_{2}$ to protect mitochondria from functional degradation by hyperoxia-induced oxidative stress. 


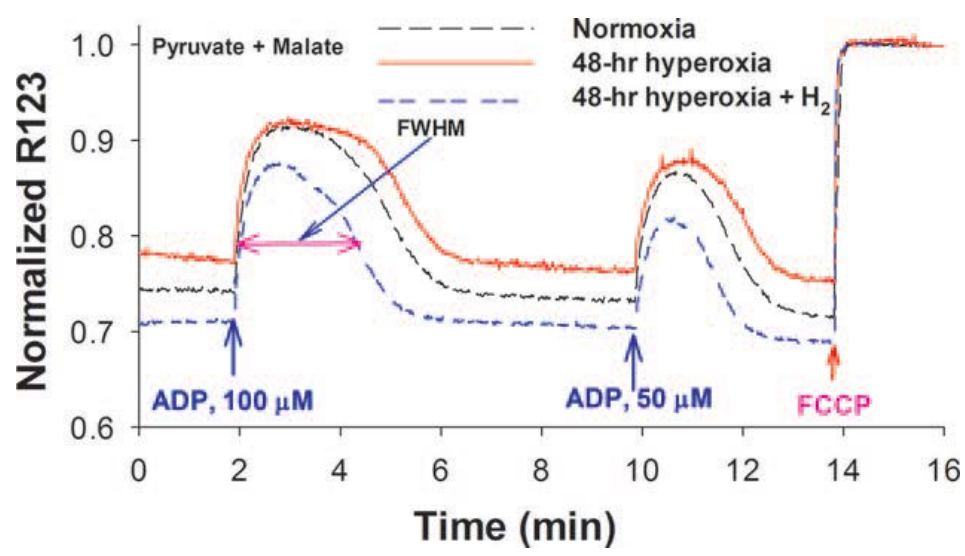

FIG. 2. Averaged R123 emission signal in mitochondria isolated from lungs of normoxia, 48-h hyperoxia, and 48-h hyperoxia $+\mathrm{H} 2$ rats. FWHM indicates full width, half maximum.

TABLE 7. $\Delta \psi_{m}$ recovery time from ADP-stimulated depolarization

\begin{tabular}{lcc}
\hline Group & $\begin{array}{c}\text { FWHM }(\min ) \\
\text { pyruvate }+ \text { malate }(n)\end{array}$ & $\begin{array}{c}\text { FWHM }(\min ) \\
\text { succinate }(\mathrm{n})\end{array}$ \\
\hline Normoxia & $1.98 \pm 0.18(7)$ & $1.75 \pm 0.16(6)$ \\
48-h: hyperoxia & $3.30 \pm 0.29^{*}(6)$ & $2.79 \pm 0.34^{*}(7)$ \\
& $(P=0.002)$ & $(P=0.036)$ \\
48-h: hyperoxia $+\mathrm{H}_{2}$ & $2.45 \pm 0.26(6)$ & $1.78 \pm 0.20(6)$ \\
\hline
\end{tabular}

Mitochondrial membrane potential $\Delta \mathrm{t}_{\mathrm{m}}$

Unpaired Student $t$ test or Mann-Whitney Rank Sum test: "different from normoxia, $\mathrm{n}$, number of rats.

FWHM indicates full width at half maximum for $100 \mathrm{mM}$ ADP-stimulated depolarization of $\Delta \psi_{\mathrm{m}}$.

$T_{A B L E}$ 7. $D c_{m}$ recovery time from ADP-stimulated depolarization

\begin{tabular}{|l|c|c|}
\hline Group & FWHM (min) pyruvate +malate $(\mathrm{n})$ & FWHM $(\min )$ succinate $(\mathrm{n})$ \\
\hline Normoxia & $1.98 \pm 0.18(7)$ & $1.75 \pm 0.16(6)$ \\
\hline 48-h: hyperoxia & $3.30 \pm 0.29^{*}(6)$ & $2.79 \pm 0.34^{*}(7)$ \\
& $(P=0.002)$ & $(P=0.036)$ \\
\hline 48-h: hyperoxia $+\mathrm{H}_{2}$ & $2.45 \pm 0.26(6)$ & $1.78 \pm 0.20(6)$ \\
\hline
\end{tabular}

Mitochondrial membrane potential

Unpaired Student $t$ test or Mann-Whitney Rank Sum test: *different from normoxia, n, number of rats.

FWHM indicates full width at half maximum for 100 mM ADP-stimulated depolarization of $\mathrm{m}$.

\section{Imaging results}

Lung uptake of ${ }^{99 \mathrm{~m}} \mathrm{Tc}-\mathrm{HMPAO}$ and ${ }^{99 \mathrm{~m}} \mathrm{Tc}$-duramycin was quantified from the biomarker images in groups of normoxia and hyperoxia rats with and without $\mathrm{H}_{2}$. Figure 3 shows representative ${ }^{99 \mathrm{~m} T c-H M P A O}$ images obtained at steady state from a normoxia rat (left), and from rats $48 \mathrm{~h}$ after exposure to either hyperoxia(middle), or hyperoxia $+\mathrm{H}_{2}$ (right), where the lung $\mathrm{ROI}$ is outlined. The images show enhanced ${ }^{99 \mathrm{~m}} \mathrm{Tc}-\mathrm{HMPAO}$ uptake in the lungs of the hyperoxia rat, which is reduced in the hyperoxia $+\mathrm{H}_{2}$ rat. Figure 4 shows lung uptake (the ratio of

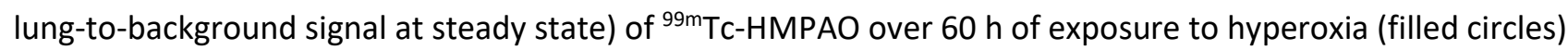
or hyperoxia $+\mathrm{H}_{2}$ (open circles). ${ }^{99 \mathrm{~m}} \mathrm{Tc}-\mathrm{HMPAO}$ uptake increased in a time-dependent manner, reaching a maximum increase of $\sim 270 \%$ at $60 \mathrm{~h}$. At each time point, inclusion of $\mathrm{H}_{2}$ in the chamber gas mixture significantly reduced ${ }^{99 \mathrm{~m} T c-H M P A O}$ uptake; at $60-\mathrm{h}$ of exposure uptake was reduced to $\sim 120 \%$ of that of normoxia rats. For a given treatment (hyperoxia, hyperoxia $+\mathrm{H}_{2}$ ), one-way ANOVA followed by Tukey range test was used to evaluate differences between means of groups at the four exposure times. Unpaired $t$ tests were used to evaluate differences between hyperoxia and hyperoxia $+\mathrm{H}_{2}$ at each time point. 

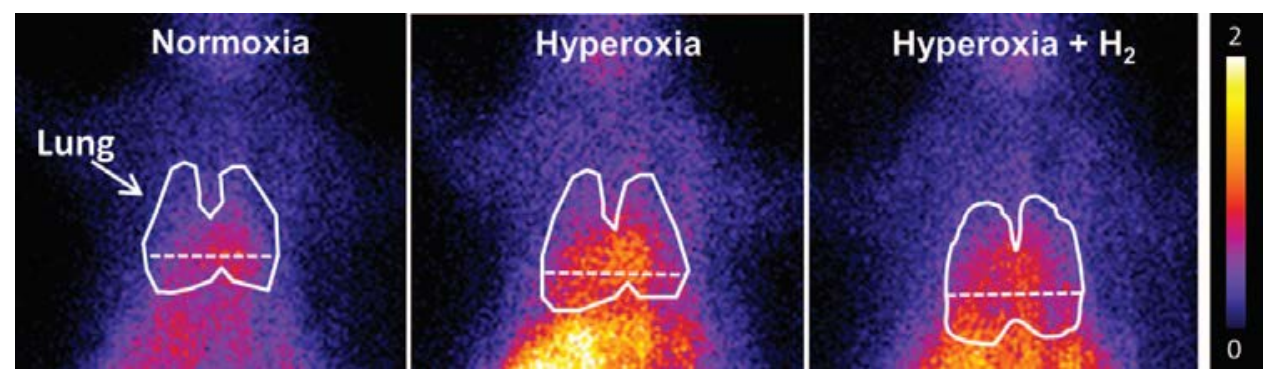

$\mathrm{F}_{\mathrm{IG}}$. 3. Representative planar images of ${ }^{99 \mathrm{~m}} \mathrm{TC}-\mathrm{HMPAO}$ distribution in a normoxia (left), 48-h hyperoxia (center), and 48-h hyperoxia $\mathrm{H}_{2}$ (right) rat 20 min following injection. Lung ROI is determined from the ${ }^{99 m}$ Tc-MAA image with the dashed horizontal lower boundary to avoid liver contribution.

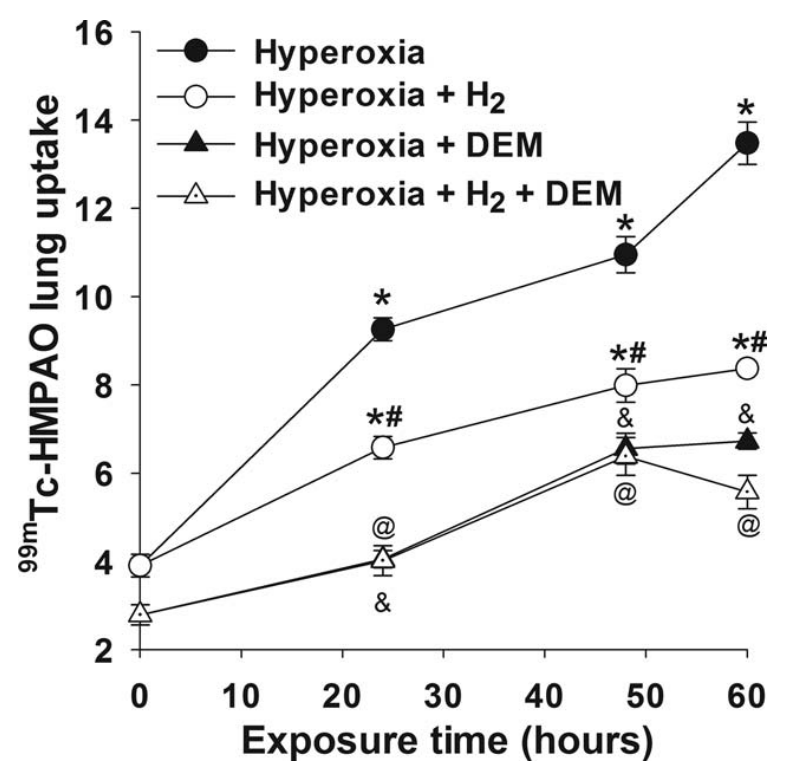

$\mathrm{F}_{\mathrm{IG}}$. 4. Lung uptake of ${ }^{99 \mathrm{~m}} \mathrm{Tc}-\mathrm{HMPAO}$ in rats exposed to hyperoxia (filled circles) or hyperoxia $+\mathrm{H}_{2}$ (open circles) for 24,48 , or $60 \mathrm{~h}$. *Different from normoxia (time $=0$ ), different from hyperoxia alone, different from hyperoxia pre DEM, ${ }^{@}$ different from hyperoxia $+\mathrm{H}_{2}$ pre DEM, all with $P<0.001 .(\mathrm{n})=$ number of rats: normoxia (7), normoxia + DEM (7), 24-h hyperoxia (5), 24-h hyperoxia + DEM (5), 24-h hyperoxia+H2 (7), 24-h hyperoxia $+\mathrm{H}_{2}+\operatorname{DEM}(7)$, 48-h hyperoxia (5), 48-h hyperoxia +DEM (5), 48-h hyperoxia $+\mathrm{H}_{2}$ (8), 48-h hyperoxia $+\mathrm{H}_{2}+$ DEM (5), 60-h hyperoxia (6), 60-h hyperoxia DEM (5), 60-h hyperoxia $\mathrm{H}_{2}(4)$, 60-h hyperoxia $\mathrm{H}_{2}(4)$.

We investigated the role of GSH in ${ }^{99 m} \mathrm{Tc}-\mathrm{HMPAO}$ lung uptake by imaging rats before and after treatment with DEM ${ }^{(12)}$. DEM treatment resulted in significantly reduced uptake in both the hyperoxia (Fig. 4, filled circles vs. filled triangles) and hyperoxia $+\mathrm{H}_{2}$ groups (open circles vs. open triangles), suggesting the role of GSH in the uptake of ${ }^{99 \mathrm{~m}} \mathrm{Tc}-\mathrm{HMPAO}$. The reduction in ${ }^{99 \mathrm{~m}} \mathrm{Tc}-\mathrm{HMPAO}$ uptake in hyperoxia (50\%) and hyperoxia+ $\mathrm{H}_{2}(33 \%)$ rats was a greater fraction than that of normoxia rats (24\%) (Fig. 4). For rats exposed to hyperoxia or hyperoxia+ $\mathrm{H}_{2}$ for $24 \mathrm{~h}$, the enhanced ${ }^{99 \mathrm{~m}} \mathrm{Tc}-\mathrm{HMPAO}$ lung uptake was mostly DEM-sensitive. On the other hand, for rats exposed to hyperoxia or hyperoxia $+\mathrm{H}_{2}$ for 48 and $60 \mathrm{~h}$, only $\sim 50 \%$ of the measured increase in ${ }^{99 \mathrm{~m} T c-H M P A O}$ lung uptake was DEM-sensitive. For a given treatment (hyperoxia + DEM, hyperoxia + $\mathrm{H}_{2}+\mathrm{DEM}$ ), one-way ANOVA followed by Tukey range test was used to evaluate differences between means of groups at the four exposure times. A paired $t$ test was used to evaluate differences pre and post DEM for a given 
group. For a given exposure time, an unpaired $t$ test was used to evaluate differences between hyperoxia and hyperoxia $+\mathrm{H}_{2}$.

Figure 5 shows representative ${ }^{99 \mathrm{~m}} \mathrm{Tc}$-duramycin images at steady state obtained from a normoxia rat (left), and from rats $60 \mathrm{~h}$ after exposure to either hyperoxia (middle), or hyperoxia $+\mathrm{H}_{2}$ (right). The enhanced ${ }^{99 \mathrm{~m} T c-}$ durmaycin uptake evident in the hyperoxia rat appears reduced in the hyperoxia $+\mathrm{H}_{2}$ rat. Figure 6 shows the time course of ${ }^{99 \mathrm{~m} T c-d u r a m y c i n}$ uptake in lungs of rats exposed to either hyperoxia (filled circles) or hyperoxia $+\mathrm{H}_{2}$ (open circles). The time-dependent increase in ${ }^{99 \mathrm{~m}} \mathrm{Tc}$-duramycin lung uptake reported

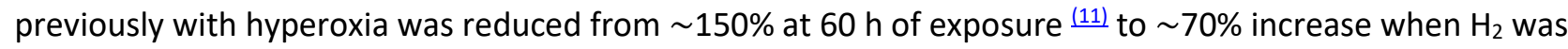
included in the chamber gas mixture. For a given treatment (hyperoxia, hyperoxia $+\mathrm{H}_{2}$ ), one-way ANOVA followed by Tukey range test was used to evaluate differences between means of groups at the three exposure times. For a given exposure time, an unpaired $t$ test was used to evaluate differences between hyperoxia and hyperoxia $+\mathrm{H}_{2}$.
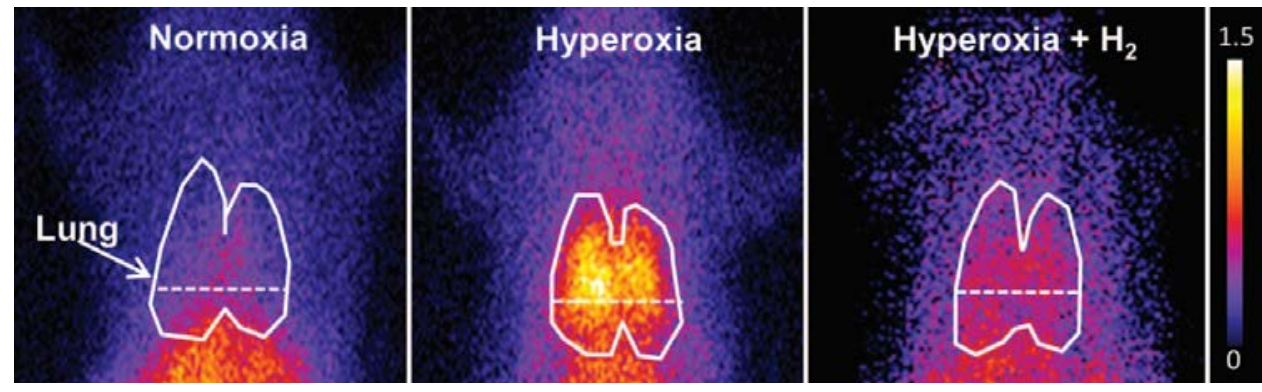

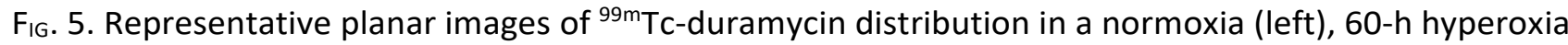
(center), and 60-h hyperoxia $\mathrm{H}_{2}$ (right) rat 20 min following injection. Lung $\mathrm{ROI}$ is determined from the ${ }^{99 m}$ Tc-MAA image with the dashed horizontal lower boundary to avoid liver contribution. ROI s region of interest.

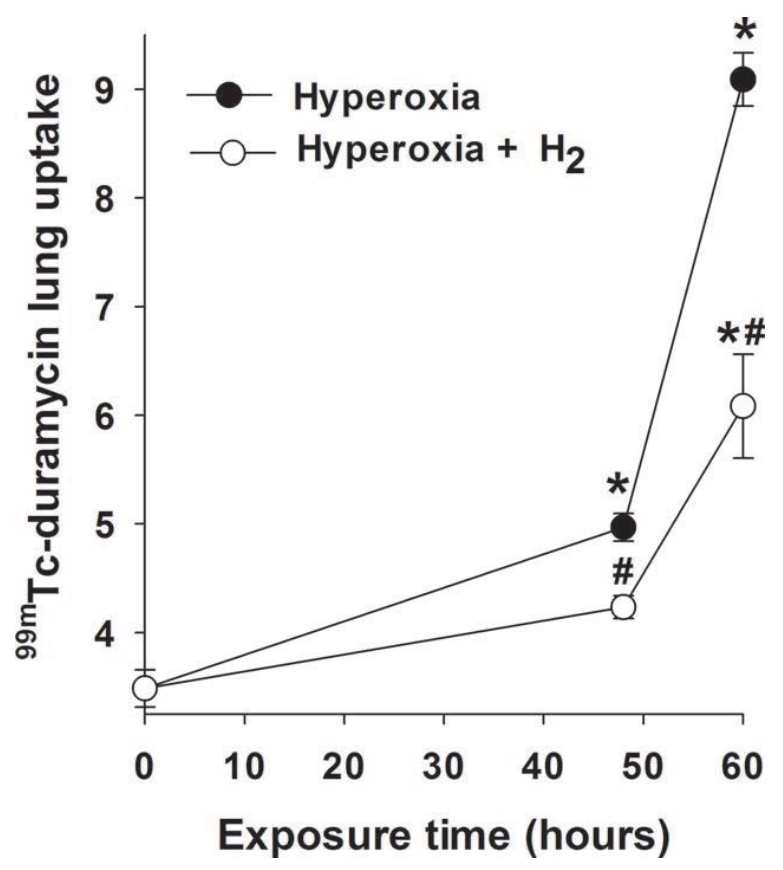

$\mathrm{F}_{\mathrm{IG}}$. 6. Lung uptake of ${ }^{99 \mathrm{~m}} \mathrm{Tc}$-duramycin in rats exposed to hyperoxia (filled circles) or hyperoxia $\mathrm{H}_{2}$ (open circles) for 48 or $60 \mathrm{~h}$. *Different from normoxia (time 0 ) with $P<0.001$, "different from hyperoxia alone 
with $P=0.001$ for $48 \mathrm{~h}$ and $P<0.001$ for 60 h. $(\mathrm{n})=$ number of rats: normoxia (9), 48-h hyperoxia (7), 48-h hyperoxia $+\mathrm{H}_{2}(6)$, 60-h hyperoxia (7), 60-h hyper-oxia $+\mathrm{H}_{2}(5)$.

\section{Lung GSH content}

Table 8 shows the results of the glutathione assays indicating that rat exposure to hyperoxia increased lung tissue GSH content after $48 \mathrm{~h}(36 \%)$ of exposure as compared with lungs of normoxia rats. Rat exposure to hyperoxia $+\mathrm{H}_{2}$ for $48 \mathrm{~h}$ reduced that increase by $42 \%$. Figure 7 suggests a strong relationship between GSH tissue content measured from lung tissue assays and in vivo ${ }^{99 \mathrm{~m}} \mathrm{Tc}-\mathrm{HMPAO}$ lung uptake determined from imaging ${ }^{(12)}$.

\begin{tabular}{lc}
\multicolumn{1}{c}{ TABLE 8. Glutathione (GSH) content of lung homogenate } \\
\hline Group (n) & GSH (fraction of normoxia) \\
\hline Normoxia (7) & $1.00 \pm 0.08$ \\
48-h: hyperoxia (7) & $1.36 \pm 0.02^{*}$ \\
& $(P<0.001)^{\star}$ \\
48-h: hyperoxia $+\mathrm{H}_{2}(6)$ & $1.21 \pm 0.03^{* \dagger}$ \\
& $(P<0.001)^{*}$ \\
& $(P<0.001)^{\dagger}$ \\
\hline GSH concentration for normoxia lungs was $9.02 \pm 0.38(\mathrm{n}=7) \mu \mathrm{mol} / \mathrm{g}$ \\
dry wt. \\
Unpaired Student $t$ test: *different from normoxia, ${ }^{\dagger}$ different from \\
hyperoxia. \\
$\mathrm{n}$ indicates number of rats.
\end{tabular}

$T_{A B L E}$ 8. Glutathione (GSH) content of lung homogenate

\begin{tabular}{|l|c|}
\hline Group (n) & GSH (fraction of normoxia) \\
\hline Normoxia (7) & $1.00 \pm 0.08$ \\
\hline 48-h: hyperoxia (7) & $1.36 \pm 0.02^{*}$ \\
& $(P<0.001)^{*}$ \\
\hline 48-h: hyperoxia $+\mathrm{H}_{2}(6)$ & $1.21 \pm 0.003^{*,+}$ \\
& $(P<0.001)^{*}$ \\
& $(\mathrm{P}<0.001)^{\dagger}$ \\
\hline
\end{tabular}

GSH concentration for normoxia lungs was $9.02 \pm 0.38(\mathrm{n} 1 / 47) \mathrm{mmol} / \mathrm{g}$ dry wt.

Unpaired Student t test: *different from normoxia, +different from hyperoxia.

$\mathrm{n}$ indicates number of rats.

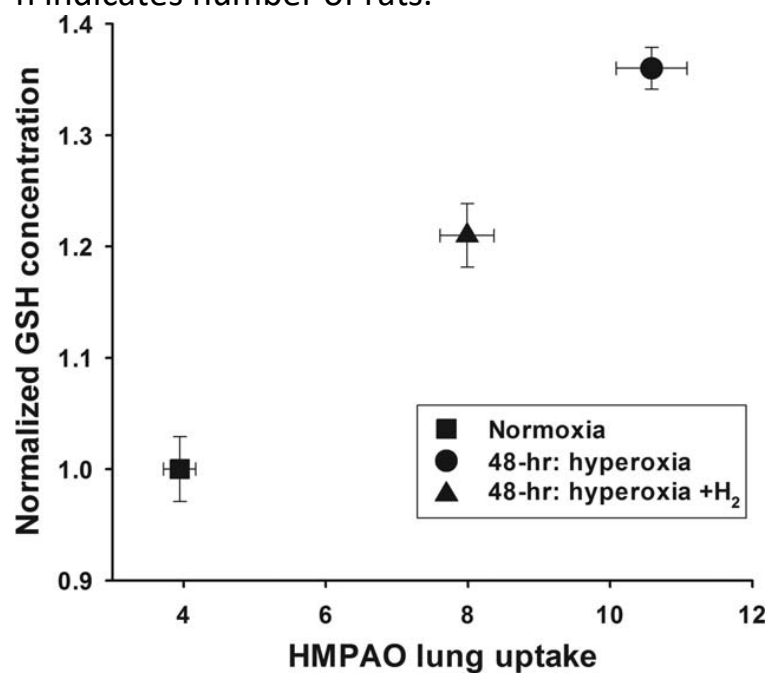

Fig. 7. Relationship between 99mTc-HMPAO lung uptake (Fig. 4 and lung tissue GSH content (as fraction of normoxia, Table 8). GSH indicates glutathione. 


\section{DISCUSSION AND CONCLUSIONS}

The present study detects and tracks the anti-oxidant and anti-apoptotic properties of $\mathrm{H}_{2}$ therapy in vivo and to demonstrate protection after as early as $24 \mathrm{~h}$ of hyperoxia exposure. The results demonstrate the ability of the

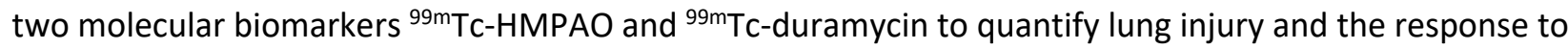
$\mathrm{H}_{2}$ treatment in vivo in rats exposed to hyperoxia as a model of human ALI/ARDS. Smaller increases in the lung uptake of both ${ }^{99 \mathrm{~m}} \mathrm{Tc}$-HMPAO and ${ }^{99 \mathrm{~m}} \mathrm{Tc}$-duramycin over the 60-h exposure period were observed in rats exposed to hyperoxia $+\mathrm{H}_{2}$ as compared with rats exposed to hyperoxia alone. These results are consistent with the anti-

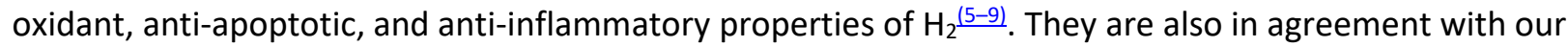
observations of decreased injury severity in $\mathrm{H}_{2}$ treated rats based on lung histology and lavage constituents, pleural effusion, and less mitochondrial dysfunction as identified by kinetic responses of isolated mitochondria.

${ }^{99 \mathrm{~m}} \mathrm{Tc}-\mathrm{HMPAO}$ was originally developed as a brain perfusion agent but its uptake and retention in several tissues serve as a marker of tissue redox state $\stackrel{(23) .}{ }{ }^{99 \mathrm{~m}} \mathrm{Tc}-\mathrm{HMPAO}$ reduction and thus its cellular retention has been shown to be strongly dependent on the oxidoreductive state of the tissue including intracellular GSH content and other factors involving mitochondrial redox state $\frac{(12)}{2}$. Recently, we demonstrated a strong correlation between ${ }^{99 \mathrm{~m}} \mathrm{Tc}$-HMPAO lung uptake and lung tissue GSH content ${ }^{(12)}$. The results of the current study (Fig. 4) show that ${ }^{99 \mathrm{~m}} \mathrm{Tc}$-HMPAO lung uptake increased steadily over the 60 -h hyperoxia exposure period, and that most of the increase was DEM-inhabitable or GSH-dependent, consistent with lung tissue response to hyperoxiainduced oxidative stress.

On the other hand, exposure to hyperoxia $+\mathrm{H}_{2}$ decreased ${ }^{99 \mathrm{~m}} \mathrm{Tc}-\mathrm{HMPAO}$ lung uptake in comparison to lung uptake in rats exposed to hyperoxia alone, and most of the decrease was in the GSH-dependent component. Since antioxidants such as GSH increase in response to oxidative stress, the effect of $\mathrm{H}_{2}$ on the DEM-sensitive portion of ${ }^{99 \mathrm{~m}} \mathrm{Tc}-\mathrm{HMPAO}$ lung uptake and on the GSH content of lung homogenate suggests that $\mathrm{H}_{2}$ treatment reduced hyperoxia-induced oxidative stress. This is reflective of $\mathrm{H}_{2}$ 's anti-oxidant properties and consistent with its ability to mitigate the hyperoxia-induced increase in 3-NT expression in our studies (Table 4). Sun et al. ${ }^{(9)}$ showed that rat exposure to hyperoxia for $60 \mathrm{~h}$ increased lung tissue superoxide dismutase (SOD) activity compared with that of normoxia rats, and that the increased SOD activity was smaller in lungs of hyperoxiaexposed rat that received multiple intraperitoneal injections of $\mathrm{H}_{2}$-rich saline during the exposure period. In that study, the anti-oxidant properties of $\mathrm{H}_{2}$ were reflected by its ability to mitigate hyperoxia-induced increase in lung tissue lipid and DNA oxidation (Table 9). Kawamura et al. (5) suggested that the $\mathrm{H}_{2}$ protective effect is via the induction of the nuclear factor erythroid two-related factor antioxidant response element (Nrf2-ARE) signaling pathway. They showed that the expressions of Nrf2-ARE dependent enzymes, including heme oxygenase (HO-1), increased more in lungs of rats exposed to hyperoxia $+\mathrm{H}_{2}$ for $60 \mathrm{~h}$ than in lungs of rats exposed to hyperoxia alone ${ }^{(5)}$. HO-1 is important for removing free heme, a source of iron which plays a key role in hydroxyl radical formation via the Fenton reaction ${ }^{(5)}$. Although the exact mechanism by which $\mathrm{H}_{2}$ exerts its antioxidant properties is still not fully understood, the results of current and previous studies suggest that the mechanism could be either by directly scavenging hydroxyl radical via an exothermic reaction $\stackrel{(8)}{\text { and/or }}$ indirectly by its effect on the expression of HO-1 $\stackrel{(5)}{~}$. 
TAQLE 9. Summary of effects of rat exposure to hyperoxia $+\mathrm{H}_{2}$ for $60 \mathrm{~h}$ compared with exposure to hyperoxia alone for $60 \mathrm{~h}$ on various

\begin{tabular}{|c|c|c|c|}
\hline & Kawamura et al. 2013 & Sun et al. 2011 & Current study \\
\hline Rat strain & Adult Lewis (male) & Adult SD (male) & Adult SD (male) \\
\hline $\mathrm{H}_{2}$ delivery & $2 \% \mathrm{H}_{2}$ gas (inhaled) & Saline-rich $\mathrm{H}_{2}$ (i.p) & $2 \% \mathrm{H}_{2}$ gas (inhaled) \\
\hline Body weight loss & Lower & NA & NS \\
\hline Lung wet weight & NA & NA & NS \\
\hline Lung wet/dry & $-8 \%$ & $-7 \%$ & $+5 \%$ \\
\hline Pleural effusion & $-40 \%$ & $-30 \%$ & $-70 \%$ \\
\hline SOD & NA & $-40 \%$ & NA \\
\hline 3-NT & NA & NA & $-51 \%$ \\
\hline 4-HNE & NA & NA & NS \\
\hline BAL protein & $-46 \%$ & NA & NA \\
\hline H\&E score & Lower & Lower & Lower \\
\hline Apoptosis & $-31 \%$ & $-33 \%$ & $-53 \%$ \\
\hline Pro-inflammatory cytokines & Lower & Lower & NA \\
\hline MDA & NA & $-40 \%$ & NA \\
\hline 8-OHdG & NA & $-49 \%$ & NA \\
\hline HO-1 expression & $+136 \%$ & NA & NA \\
\hline NQO1 expression & $+93 \%$ & NA & NA \\
\hline GSTA2 expression & $+158 \%$ & NA & NA \\
\hline Prdx1 expression & $+105 \%$ & NA & NA \\
\hline
\end{tabular}

8-OHdG indicates 8-hydroxy-2 -deoxyguanosine: GSTA2, glutathione S-transferase A2; MDA, malondialdehyde: NA, not available; NS, not significant: Prdx1, peroxiredoxin 1: SOD, superoxid

TABLE 9. Summary of effects of rat exposure to hyperoxia $+\mathrm{H} 2$ for $60 \mathrm{~h}$ compared with exposure to hyperoxia alone for $60 \mathrm{~h}$ on various antioxidant enzymes and indices of lung injury

\begin{tabular}{|l|c|c|c|}
\hline & Kawamura et al. 2013 & Sun et al. 2011 & Current study Rat \\
\hline Rat strain & Adult Lewis (male) & Adult SD (male) & Adult SD (male) \\
\hline $\mathrm{H}_{2}$ delivery & $2 \% \mathrm{H}_{2}$ gas (inhaled) & Saline-rich $\mathrm{H}_{2}$ (i.p.) & $2 \% \mathrm{H}_{2}$ gas (inhaled) \\
\hline Body weight loss & Lower & $\mathrm{NA}$ & $\mathrm{NS}$ \\
\hline Lung wet weight & $\mathrm{NA}$ & $\mathrm{NA}$ & $\mathrm{NS}$ \\
\hline Lung wet/dry & $-8 \%$ & $-7 \%$ & $+5 \%$ \\
\hline Pleural effusion & $-40 \%$ & $-30 \%$ & $-70 \%$ \\
\hline SOD & $\mathrm{NA}$ & $-40 \%$ & $\mathrm{NA}$ \\
\hline 3-NT & $\mathrm{NA}$ & $\mathrm{NA}$ & $-51 \%$ \\
\hline 4-HNE & $\mathrm{NA}$ & $\mathrm{NA}$ & $\mathrm{NS}$ \\
\hline BAL protein & $-46 \%$ & $\mathrm{NA}$ & $\mathrm{NA}$ \\
\hline H\&E score & Lower & Lower & Lower \\
\hline Apoptosis & $-31 \%$ & $-33 \%$ & $-53 \%$ \\
\hline Pro-inflammatory cytokines & Lower & Lower & NA \\
\hline MDA & $\mathrm{NA}$ & $-40 \%$ & $\mathrm{NA}$ \\
\hline 8-OHdG & $\mathrm{NA}$ & $-49 \%$ & $\mathrm{NA}$ \\
\hline HO-1 expression & $+136 \%$ & $\mathrm{NA}$ & $\mathrm{NA}$ \\
\hline NQO1 expression & $+93 \%$ & $\mathrm{NA}$ & $\mathrm{NA}$ \\
\hline GSTA2 expression & $+158 \%$ & $\mathrm{NA}$ & $\mathrm{NA}$ \\
\hline Prdx1 expression & $+105 \%$ & $\mathrm{NA}$ & $\mathrm{NA}$ \\
\hline 8-OHdG indicates 8-hydroxy-2 & $-\mathrm{NA} \%$ & \\
\hline
\end{tabular}

8-OHdG indicates 8-hydroxy-2' -deoxyguanosine; GSTA2, glutathione S-transferase A2; MDA, malondialdehyde; NA, not available; NS, not significant;

Prdx1, peroxiredoxin 1; SOD, superoxide dismutase.

The increase in GSH content of lung homogenate (+36\% for 48 -h hyperoxia and $+21 \%$ for 48 -

$\mathrm{h}$ hyperoxia $+\mathrm{H}_{2}$ compared with normoxia) is lower than the $\sim 100 \%$ to $170 \%$ increase in HMPAO lung uptake measured from the in vivo images and the $\sim 50 \%$ to $280 \%$ increase in the DEM-sensitive portion of the HMPAO lung uptake. One explanation for this difference could be the fact that the GSH content reported in this study is the average GSH content of all lung cells and alveolar fluid. Although the results of this study do not provide information regarding the specific types of lung cells contributing to the lung uptake and retention of HMPAO, previous studies have suggested that its retention is predominantly attributable to endothelial cells $\frac{(24,25)}{\text {, which }}$ account for $\sim 50 \%$ of lung cells and are in direct contact with blood ${ }^{(4)}$. Other studies have also demonstrated that different cell types have different GSH content, and oxidant stress has different effects on the GSH content 
of these cells $\underline{(26,27)}$. For instance, Deneke et al. $\underline{(26)}$ demonstrated that exposure of endothelial cells to hyperoxia $\left(85 \% \mathrm{O}_{2}\right.$ for $48 \mathrm{~h}$ ) increased GSH content by $85 \%$. On the other hand, neutrophil GSH content is not sensitive to oxidant injury ${ }^{(27)}$. Thus, depending on the GSH content of the various lung cells and how the GSH content of these cells change in response to exposure to hyperoxia, the GSH content in lung homogenate measured in this study may overestimate or underestimate the effect of hyperoxia or hyperoxia $+\mathrm{H}_{2}$ on $\mathrm{GSH}$ content of pulmonary capillary endothelial cells.

${ }^{99 m}$ Tc-duramycin serves as a molecular probe that binds to phosphatidylethanolamine, which has little presence on the surface of normal viable cells, but becomes exposed onto the cell surface and/or accessible to the extracellular milieu with apoptosis and necrosis, respectively 11,28$)$. Previously, we reported an increase in the lung uptake of ${ }^{99 \mathrm{~m}} \mathrm{Tc}$-duramycin in rats exposed to hyperoxia or radiation, and demonstrated a strong correlation between ${ }^{99 \mathrm{~m}} \mathrm{Tc}$-duramycin lung uptake and cleaved caspase 3 positive cells, predominantly endothelial cells $\stackrel{(11,}{ }$ 14). Figure 6 shows that ${ }^{99 \mathrm{~m}} \mathrm{Tc}$-duramycin lung uptake was significantly lower in lungs of rats exposed to hyperoxia $+\mathrm{H}_{2}$ as compared with that in lungs of rats exposed to hyperoxiaalone $\stackrel{(11)}{\text {, }}$, reflective of the antiapoptotic properties of $\mathrm{H}_{2}(5,8,9)$. This result is consistent with those reported by others (Table 9). For instance, Sun et al. (9) reported that $\mathrm{H}_{2}$ treatment mitigated hyperoxia-induced increases in TUNEL positive lung cells. Kawamura et al. ${ }^{(5)}$ demonstrated the ability of $\mathrm{H}_{2}$ to protect against hyperoxia-induced increases in the number of caspase 3 positive lung cells. Additional results show that $\mathrm{H}_{2}$ inhibited hyperoxia-induced increases in the expression of the anti-apoptotic protein $\mathrm{Bcl}-2$ and decreases in the expression of the pro-apoptotic protein Bax ${ }^{(5)}$. Dixon et al. ${ }^{(8)}$ suggested that $\mathrm{H}_{2}$ 's anti-apoptotic effect is via its ability to inhibit the activation of caspase3.

The anti-inflammation properties of $\mathrm{H}_{2}$ are reflected in the histological (ig. 1) and BAL (Table 6) results, which show less cellular infiltration in lungs of rats exposed to hyperoxia $+\mathrm{H}_{2}$ compared with those exposed to hyperoxia. These results are consistent with other studies (Table 9) that demonstrated the ability of $\mathrm{H}_{2}$ to mitigate hyperoxia-induced increases in BAL protein, histology, and levels of pro-inflammatory cytokines in lung tissue $\frac{(5,9)}{}$.

Isolated mitochondria studies using R123 ( $\underline{\text { Fig. } 2}$, Table 7) suggest the ability of $\mathrm{H}_{2}$ to provide mitochondrial electron transport chain with partial protection from hyperoxia-induced oxidative stress. We previously demonstrated significant decreases in complex I and II activities in lung of rats exposed to hyperoxia for $48 \mathrm{~h}$ (22).

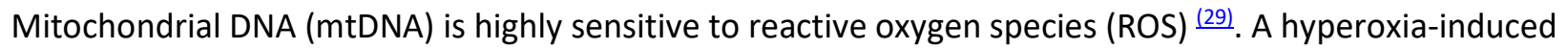
increase in the rate of ROS formation could damage mtDNA and as a result compromise complex I activity since 7 of 45 subunits of complex I are encoded by mtDNA 29,30$)$. This increase in ROS formation could also cause direct alteration to complex I activity by oxidizing the key phospholipid cardiolipin, which is sensitive to ROS $\underline{(31}$, 32). Oxidation of cardiolipin could lead to an increase in the loss of electrons at complex I and in the rate of mitochondrial superoxide formation at complex I ${ }^{31,32)}$. Furthermore, cardiolipin oxidation can affect complex II

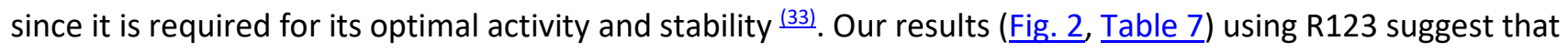
$\mathrm{H}_{2}$ partially protected complex I and II activities from oxidative stress.

In the present study, the effect of $\mathrm{H}_{2}$ on hyperoxia-induced body weight loss and increase in lung wet/dry weight ratio after $60 \mathrm{~h}$ of exposure (Tables 2 and 3 ) are not consistent with those reported by other studies (Table 9 ). For instance, both Sun et al. and Kawamura et al. reported lower lung wet/dry weight ratios in rats treated with hyperoxia $+\mathrm{H}_{2}$ as compared with rats treated with hyperoxia $\frac{(5,9)}{}$. In addition, Kawamura et al. ${ }^{(5)}$ reported that $\mathrm{H}_{2}$ reduced rat body weight loss after $60 \mathrm{~h}$ of exposure to hyperoxia. The difference between these results and results of the current study could be due to differences in rat strains (Sprague-Dawley vs. Lewis rats in Kawamura et al. (5)) or in $\mathrm{H}_{2}$ administration (intraperitoneal injection of $\mathrm{H}_{2}$-rich saline in Sun et al. ${ }^{(9)}$ ). Xie et al. $\stackrel{(10)}{ }$ showed that the protective effects of $\mathrm{H}_{2}$ against sepsis-induced lung injury are dose dependent over $1 \%$ to 
$4 \%$ range. Thus, additional protection might be observed in Sprague-Dawley rats with higher concentrations of $\mathrm{H}_{2}$ than the $2 \%$ used in the present study.

Several gaseous therapies have been evaluated for hyperoxia-induced ALI/ARDS, including nitric oxide (NO), carbon monoxide (CO), and $\mathrm{H}_{2}{ }^{(8,34,35)}$. Like $\mathrm{NO}$ and $\mathrm{CO}, \mathrm{H}_{2}$ is highly permeable across various cellular barriers and hence capable of accessing key cellular compartments such as mitochondrion which appear to play a key role in the pathogenesis of human ALI/ARDS. However, $\mathrm{H}_{2}$ is advantageous since it does not affect the physiological or immune response of key ROS (superoxide and hydrogen peroxide). Moreover, $\mathrm{H}_{2}$ is not toxic at high concentrations and is safe at concentrations $<4.1 \%$ when mixed with $\mathrm{O}_{2}\left(\frac{8)}{}\right.$.

In conclusion, the results suggest the potential translational utility of imaging with two SPECT biomarkers, one of which is already in clinical use, for in vivo assessment of key cellular pathways involved in the pathogenesis of ALI/ARDS and for monitoring responses to potential therapies such as inhaled $\mathrm{H}_{2}$ gas.

\section{Acknowledgments}

The authors thank Ying Gao and Jayashree Narayanan for their help with tissue assays, and Dr Raphael Fraser for his assistance with the statistical review.

\section{REFERENCES}

1. Bellani G, Laffey JG, Pham T, Fan E, Brochard L, Esteban A, Gattinoni L, van Haren F, Larsson A, McAuley DF, et al. Epidemiology, patterns of care, and mortality for patients with acute respiratory distress syndrome in intensive care units in 50 countries. JAMA 2016; 315:788-800.

2. Matthay MA, Zemans RL. The acute respiratory distress syndrome: pathogenesis and treatment. Annu Rev Patho/2011; 6:147-163.

3. Girardis M, Busani S, Damiani E, Donati A, Rinaldi L, Marudi A, Morelli A, Antonelli M, Singer M. Effect of conservative vs conventional oxygen therapy on mortality among patients in an intensive care unit: the Oxygen-ICU randomized clinical trial. JAMA 2016; 316:1583-1589.

4. Crapo JD, Barry BE, Foscue HA, Shelburne J. Structural and biochemical changes in rat lungs occurring during exposures to lethal and adaptive doses of oxygen. Am Rev Respir Dis 1980; 122:123-143.

5. Kawamura T, Wakabayashi N, Shigemura N, Huang CS, Masutani K, Tanaka Y, Noda K, Peng X, Takahashi T, Billiar TR, et al. Hydrogen gas reduces hyperoxic lung injury via the Nrf2 pathway in vivo. Am J Physiol Lung Cell Mol Physiol 2013; 304:L646-L656.

6. Ohta S. Molecular hydrogen is a novel antioxidant to efficiently reduce oxidative stress with potential for the improvement of mitochondrial diseases. Biochim Biophys Acta 2012; 1820:586-594.

7. Ohsawa I, Ishikawa M, Takahashi K, Watanabe M, Nishimaki K, Yamagata K, Katsura K, Katayama Y, Asoh S, Ohta $\mathrm{S}$. Hydrogen acts as a therapeutic antioxidant by selectively reducing cytotoxic oxygen radicals. Nat Med 2007; 13:688-694.

8. Dixon BJ, Tang J, Zhang JH. The evolution of molecular hydrogen: a noteworthy potential therapy with clinical significance. Med Gas Res 2013; 3:10.

9. Sun Q, Cai J, Liu S, Liu Y, Xu W, Tao H, Sun X. Hydrogen-rich saline provides protection against hyperoxic lung injury. J Surg Res 2011; 165:e43-e49.

10. Xie K, Yu Y, Huang Y, Zheng L, Li J, Chen H, Han H, Hou L, Gong G, Wang G. Molecular hydrogen ameliorates lipopolysaccharide-induced acute lung injury in mice through reducing inflammation and apoptosis. Shock 2012; 37:548-555.

11. Audi SH, Jacobs ER, Zhao M, Roerig DL, Haworth ST, Clough AV. In vivo detection of hyperoxia-induced pulmonary endothelial cell death using (99m)Tc-duramycin. Nucl Med Biol 2015; 42:46-52. 
12. Audi SH, Clough AV, Haworth ST, Medhora M, Ranji M, Densmore JC, Jacobs ER. 99MTchexamethylpropyleneamine oxime imaging for early detection of acute lung injury in rats exposed to hyperoxia or lipopolysaccharide treatment. Shock 2016; 46:420-430.

13. Clough AV, Audi SH, Haworth ST, Roerig DL. Differential lung uptake of $99 \mathrm{mTc}$-hexamethylpropyleneamine oxime and 99mTc-duramycin in the chronic hyperoxia rat model. J Nucl Med 2012; 53:1984-1991.

14. Medhora M, Haworth S, Liu Y, Narayanan J, Gao F, Zhao M, Audi S, Jacobs ER, Fish BL, Clough AV. Biomarkers for radiation pneumonitis using noninvasive molecular imaging. J Nucl Med 2016; 57:1296-1301.

15. Matute-Bello G, Downey G, Moore BB, Groshong SD, Matthay MA, Slutsky AS, Kuebler WM. An official American Thoracic Society workshop report: features and measurements of experimental acute lung injury in animals. Am J Respir Cell Mol Biol 2011; 44:725-738.

16. Densmore JC, Jeziorczak PM, Clough AV, Pritchard KA Jr, Cummens B, Medhora M, Rao A, Jacobs ER. Rattus model utilizing selective pulmonary ischemia induces bronchiolitis obliterans organizing pneumonia. Shock 2013; 39:271-277.

17. Sirker A, Murdoc CE, Protti A, Sawyer GJ, Santos CX, Martin D, Zhang X, Brewer AC, Zhang M, Shah AM. Cellspecific effects of Nox2 on the acute and chronic response to myocardial infarction. $J$ Mol Cell Cardiol 2016; 98:11-17.

18. Smith IJ, Godinez GL, Singh BK, McCaughey KM, Alcantara RR, Gururaja T, Ho MS, Nguyen HN, Friera AM, White KA, et al. Inhibition of Janus kinase signaling during controlled mechanical ventilation prevents ventilation-induced diaphragm dysfunction. FASEB J 2014; 28:2790-2803.

19. Huang M, Camara AK, Stowe DF, Qi F, Beard DA. Mitochondrial inner membrane electrophysiology assessed by rhodamine-123 transport and fluorescence. Ann Biomed Eng 2007; 35:1276-1285.

20. Audi SH, Roerig DL, Haworth ST, Clough AV. Role of glutathione in lung retention of $99 \mathrm{mTc}$ hexamethylpropyleneamine oxime in two unique rat Models of hyperoxic lung injury. J Appl Physiol 2012; 113:658-665.

21. Gan Z, Audi SH, Bongard RD, Gauthier KM, Merker MP. Quantifying mitochondrial and plasma membrane potentials in intact pulmonary arterial endothelial cells based on extracellular disposition of rhodamine dyes. Am J Physiol Lung Cell Mol Physiol 2011; 300:L762-772.

22. Sepehr R, Audi SH, Staniszewski KS, Haworth ST, Jacobs ER, Ranji M. Novel flurometric tool to assess mitochondrial redox state of isolated perfused rat lungs after exposure to hyperoxia. IEEE J Transl Eng Health Med2013; 1: pii: 1500210.

23. Neirinckx RD, Burke JF, Harrison RC, Forster AM, Andersen AR, Lassen NA. The retention mechanism of technetium-99m-HM-PAO: intracellular reaction with glutathione. J Cereb Blood Flow Metab 1988; 8:S412.

24. Kuo SJ, Yang KT, Chen DR. Objective and noninvasive detection of sub-clinical lung injury in breast cancer patients after radiotherapy. Eur J Surg Oncol 2005; 31:954-957.

25. Suga K, Uchisako H, Nishigauchi K, Shimizu K, Kume N, Yamada N, Nakanishi T. Technetium-99m-HMPAO as a marker of chemical and irradiation lung injury: experimental and clinical investigations. J Nucl Med 1994; 35:1520-1527.

26. Deneke SM, Steiger V, Fanburg BL. Effect of hyperoxia on glutathione levels and glutamic acid uptake in endothelial cells. J Appl Physiol 1987; 63:1966-1971.

27. Durak H, Kilinc O, Ertay T, Ucan ES, Kargi A, Kaya GC, Sis B. Tc-99m-HMPAO uptake by bronchoalveolar cells. Ann Nucl Med 2003; 17:107-113.

28. Zhao M, Li Z, Bugenhagen S. 99mTc-labeled duramycin as a novel phosphatidylethanolamine-binding molecular probe. J Nucl Med 2008; 49:1345-1352.

29. Ruchko M, Gorodnya O, LeDoux SP, Alexeyev MF, Al-Mehdi AB, Gillespie MN. Mitochondrial DNA damage triggers mitochondrial dysfunction and apoptosis in oxidant-challenged lung endothelial cells. Am J Physiol Lung Cell Mol Physiol 2005; 288:L530-L535. 
30. Swalwell H, Kirby DM, Blakely EL, Mitchell A, Salemi R, Sugiana C, Compton AG, Tucker EJ, Ke BX, Lamont PJ, et al. Respiratory chain complex I deficiency caused by mitochondrial DNA mutations. Eur J Hum Genet 2011; 19:769-775.

31. Paradies G, Petrosillo G, Pistolese M, Ruggiero FM. Reactive oxygen species affect mitochondrial electron transport complex I activity through oxidative cardiolipin damage. Gene 2002; 286:135-141.

32. Chicco AJ, Sparagna GC. Role of cardiolipin alterations in mitochondrial dysfunction and disease. Am J Physiol Cell Physiol 2007; 292:C33-44.

33. Schwall CT, Greenwood VL, Alder NN. The stability and activity of respiratory complex II is cardiolipindependent. Biochim Biophys Acta 2012; 1817:1588-1596.

34. Otterbein LE, Mantell LL, Choi AM. Carbon monoxide provides protection against hyperoxic lung injury. Am J Physiol 1999; 276:L688-694.

35. Nelin LD, Welty SE, Morrisey JF, Gotuaco C, Dawson CA. Nitric oxide increases the survival of rats with a high oxygen exposure. Pediatr Res 1988; 43:727-732.

\section{Keywords:}

${ }^{99 m}$ Tc-durmaycin; ${ }^{99 m}$ Tc-HMPAO; acute respiratory distress syndrome; hyperoxia; SPECT imaging 